Discussion Paper No. 10-065

The Impact of Regulation-driven Environmental Innovation on Innovation Success and Firm Performance

Klaus Rennings and Christian Rammer

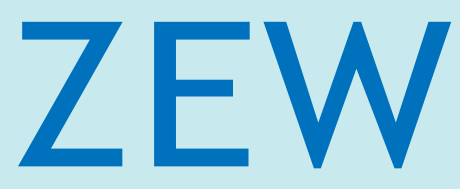

Zentrum für Europäische Wirtschaftsforschung $\mathrm{GmbH}$

Centre for European

Economic Research 
Discussion Paper No. 10-065

\title{
The Impact of Regulation-driven Environmental Innovation on Innovation Success and Firm Performance
}

\author{
Klaus Rennings and Christian Rammer
}

Download this ZEW Discussion Paper from our ftp server:

ftp://ftp.zew.de/pub/zew-docs/dp/dp10065.pdf

Die Discussion Papers dienen einer möglichst schnellen Verbreitung von neueren Forschungsarbeiten des ZEW. Die Beiträge liegen in alleiniger Verantwortung der Autoren und stellen nicht notwendigerweise die Meinung des ZEW dar.

Discussion Papers are intended to make results of ZEW research promptly available to other economists in order to encourage discussion and suggestions for revisions. The authors are solely responsible for the contents which do not necessarily represent the opinion of the ZEW. 


\section{Non technical summary}

It is widely agreed in the literature that environmental innovation is not only determined by market pull and technology push factors but also depends on regulatory incentives. There is an ongoing debate on how regulation-driven environmental innovations influence innovation and firm success. Can firms succeed in the market with innovations stimulated by environmental regulation, i.e. can they achieve a similar market success compared to innovations triggered by market demand or by new technological developments?

The positive answer is known as the Porter hypothesis which calls for a certain strictness of environmental policy. In general, the Porter hypothesis suggests that strict environmental policy spurs "innovation offsets". Increases in resource efficiency lead to higher economic efficiency, at least in the long run. These arguments are however still based on case studies. We want to validate the hypothesis by analysing regulation-driven environmental innovations.

The impact of environmental innovations on firm performance is ambiguous. On the one hand, regulatory-driven environmental innovation may impose additional costs to firms and lower their profits. On the other hand, eco-innovators could profit from lower uncertainty in innovation due to regulatory standards and demand-generating effects. We analyse (a) whether regulation-driven environmental innovation generate similar innovation success compared to other types of product and process innovation, and (b) whether regulation-driven environmental innovation increase or decrease firm success (as measured by return on sales).

Using firm data from the German innovation survey (the "Mannheim Innovation Panel”), we find that both product and process innovations driven by environmental regulation generate similar success in terms of sales with new products and cost savings as other innovations do. However, we find different effects when looking on the field of regulation that triggered innovations. Regulations in favour of sustainable mobility contribute to higher sales with market novelties while regulations in the field of water management lower this type of innovation success. With regard to a firm's price-cost margin, new processes implemented in order to comply with environmental regulation requirements lower profitability, indicating higher costs for this type of innovation which cannot be passed on prices. Higher profit margins can be observed for firms with innovations triggered by regulations on recycling and waste management as well as on resource efficiency.

Summing up, environmental innovators on average do not perform worse compared to other innovations. This means that Porter is right when saying that environmental innovations do not harm the competitiveness of firms in general. However, if we look at specific environmental policy fields, we find winners and losers of environmental policy. For example, the innovators in the vehicle sector - e.g. suppliers of the automobile industry - have achieved above average sales shares, whereas the adopters of these innovations in the transport industry had to pay the costs, and may have in fact experienced a loss of competitiveness. 


\section{Das Wichtigste in Kürze}

Es ist in der Literatur weitgehend anerkannt, dass Umweltinnovationen nicht nur markt- und technologiegetrieben sind, sondern dass auch staatliche Regulierung ein wesentlicher Impulsgeber ist. Die Auswirkungen von regulierungsgetriebenen Umweltinnovationen auf den Innovations- und Geschäftserfolg von Unternehmen sind seit langem Gegenstand kontroverser Debatten. Die zentrale Frage ist, ob sich Unternehmen mit Umweltinnovationen ähnliche Markterfolge erzielen wie mit anderen (markt- oder technologiegetriebenen) Innovationen.

Die positive Antwort auf diese Frage ist bekannt als die „Porter-Hypothese“. Generell postuliert die Porter-Hypothese, dass eine strikte Umweltpolitik positive Innovationseffekte generiert, d.h. die regulierungsbedingten Kosten der Einführung von Maßnahmen zur Verringerung der Umweltbelastung werden kurzfristig zumindest teilweise durch steigende Erlöse oder Kosteneinsparungen (z.B. für Energie, Wasser oder Abfall) verringert, langfristig können sie sogar überkompensiert werden. Verbesserungen der Ressourceneffizienz führen so langfristig zu einer verbesserten ökonomischen Effizienz. Porter stützte sich bei seiner Hypothese allerdings lediglich auf Fallstudien, d.h. auf anekdotische Evidenz. Ziel dieses Papiers ist es, die Hypothese mit Hilfe der Analyse von Daten einer Breitenbefragung zu regulierungsbedingten Umweltinnovationen zu testen.

Die Wirkungen von Umweltinnovationen auf den Unternehmenserfolg sind grundsätzlich ambivalent. Einerseits stellen Umweltinnovationen zusätzliche Kosten für das innovierende Unternehmen dar und verringern dadurch die Rendite. Andererseits können Anbieter von Umwelttechnologien aber von einer geringeren Unsicherheit bei den Nachfragern nach Umwelttechnologien profitieren, die sich durch regulatorische Standards und nachfragestimulierende Effekte von Regulierungen (z.B. Einführungsverpflichtungen) ergeben. Wir untersuchen, (a) ob regulierungsgetriebene Umweltinnovationen einen ähnlichen Innovationserfolg bewirken wie andere Arten von Produkt- und Prozessinnovationen, und (b) ob sie positive oder negative Effekte auf den Gewinn der Unternehmen haben.

Die Analyse, die auf Daten des Mannheimer Innovationspanels (MIP) basiert, zeigt, dass regulierungsbedingte Umweltinnovationen (sowohl Produkt- als auch Prozessinnovationen) einen vergleichbaren Innovationserfolg aufweisen können wie andere Innovationen. Es gibt allerdings Unterschiede bezüglich der verschiedenen Felder der Umweltpolitik. Regulierungsbedingte Innovationen im Bereich der nachhaltigen Mobilität sind beispielsweise erfolgreicher als Innovationen im Bereich des Wassermanagements. Bezüglich des Unternehmenserfolges zeigt sich ein positiver Effekt bei Produktinnovatoren im Bereich Recycling und Abfallmanagement. Für Unternehmen, die umweltfreundliche Technologien im Bereich nachhaltige Mobilität adoptieren, verschlechtert sich dagegen die Umsatzrendite aufgrund von höheren Kosten dieser Prozessinnovationen, denen kaum Kosteneinsparungen gegenüber stehen.

Zusammenfassend lässt sich sagen, dass Umweltinnovationen im Durchschnitt nicht weniger erfolgreich sind als andere Innovationen. Die Feststellung Porters, dass Ressourceneffizienz positiv zur ökonomischen Effizienz beitragen kann, und die Wettbewerbsfähigkeit nicht zwangsläufig verschlechtern muss, kann bestätigt werden. Es gibt aber Gewinner und Verlierer von Umweltpolitik. Die Gewinner finden sich auf Seiten der Technologieanbieter, wie z.B. der Automobilindustrie, während die Adaptoren dieser Technologien die Kosten zu bezahlen haben, und eine Verschlechterung ihrer Wettbewerbsposition hinnehmen müssen. 


\title{
The Impact of Regulation-driven Environmental Innova- tion on Innovation Success and Firm Performance
}

\author{
Klaus Rennings ${ }^{1}$, Christian Rammer \\ Centre for European Economic Research (ZEW)
}

Mannheim, August 2010

\begin{abstract}
The impact of environmental innovations on firm performance is ambiguous. On the one hand, regulatory-driven environmental innovation may impose additional costs to firms and lower their profits. On the other hand, eco-innovators could profit from lower uncertainty in innovation due to regulatory standards and demand-generating effects of regulation. In this paper we analyse (a) whether regulation-driven environmental innovation generate similar innovation success compared to other types of product and process innovation, and (b) whether regulation-driven environmental innovation increase or decrease firm success (as measured by return on sales). Using firm data from the German innovation survey, we find that both product and process innovations driven by environmental regulation generate similar success in terms of sales with new products and cost savings as other innovations do. However, we find different effects when looking on the field of environmental regulation that triggered innovations. Regulations in favour of sustainable mobility contribute to higher sales with market novelties while regulations in the field of water management lower this type of innovation success. With regard to a firm's price-cost margin, new processes implemented in order to comply with environmental regulation requirements lower profitability, indicating higher costs for this type of innovation which cannot be passed on prices. Higher profit margins can be observed for firms with innovations triggered by regulations on recycling and waste management as well as on resource efficiency.
\end{abstract}

Key words: Environmental Innovation, Environmental Regulation, Innovation Success, Porter Hypothesis

JEL: Q55, Q58, L51, O31, L25

Acknowledgement: The authors would like to thank two anonymous referees for their useful comments. The usual disclaimer applies.

1 Corresponding author: Centre for European Economic Research (ZEW), P.O. Box 103443, D-68034 Mannheim, Email: rennings@zew.de 


\section{Introduction}

It is widely agreed in the literature that environmental innovation is not only determined by market pull and technology push factors but also depends on regulatory incentives. There is an ongoing debate on how regulation-driven environmental innovations influence innovation and firm success. Can firms succeed in the market with innovations stimulated by environmental regulation, i.e. can they achieve a similar market success compared to innovations triggered by market demand or by new technological developments? The positive answer to this question is known as the Porter hypothesis (Porter and van der Linde, 1995a; 1995b) which calls for a certain strictness of environmental policy. In general, the Porter hypothesis suggests that strict environmental policy spurs “innovation offsets”. Increases in resource efficiency lead to higher economic efficiency, at least in the long run. Ashford et al. (1985) argued that strict regulation can induce fundamental technological changes in firms. These arguments are however still based on a series of case studies. Thus we want to validate the hypothesis by focussing on regulation-driven environmental innovations. For other environmental innovations which are not driven by regulation but by market demand or cost savings, we refer to other papers such as Rennings and Rammer (2009).

While innovation activities in general are found to positively influence the competitiveness and growth of firms (see Peters, 2008), this might be somewhat different with regard to innovations driven by environmental regulation. The primary effect of environmental innovation activity is aimed at reducing negative externalities of entrepreneurial activity. Reducing negative externalities may entail higher costs at the side of producers without generating additional income for them. This is all the more true for end-of-pipe technologies (Frondel et al., 2007), but also cleaner production technologies may lead to higher production costs compared to doing business without such environmental measures.

Against this background, we attempt to analyse in this paper the impacts of innovations driven by environmental regulation on innovation success and economic performance of the innovating firms. We employ a large data set which covers innovation activities of firms in Germany across many industries and technologies, allowing us to derive conclusions beyond case study evidence. Our paper is structured as follows: Section 2 defines environmental innovation and regulation, and reviews the literature. Section 3 describes our data, describing the underlying survey, how we measure regulation, and the sectoral distribution. In section 4 and 5 we present our model and estimation results for a) the impact of regulation-driven envi- 
ronmental innovations on innovation success and b) on firm performance. Section 6 draws some conclusions.

\section{Key definitions and literature review}

\subsection{Environmental innovation}

Environmental innovations are commonly defined according to the guidelines for empirical innovation research derived from the Oslo Manual (OECD and Eurostat, 2005). Following the Manual, environmental innovations may be defined as product or process innovations as well as organisational or marketing innovations that reduce environmental impacts either during the phase of production or during the utilisation of the good or service. In a recent study „Measuring Environmental Innovation“ the following definition has been put forward: "Ecoinnovation is the production, application or exploitation of a good, service, production process, organisational structure, or management or business method that is novel to the firm or user and which results, throughout its life cycle, in a reduction of environmental risk, pollution and the negative impacts of resources use (including energy use) compared to relevant alternatives” (Kemp and Pearson, 2007).

The definition highlights three characteristics of environmental innovations. First, an environmental innovations has to be novel only for the firm which is introducing this innovation, which is different from novelty for the market or the world. Thus an environmental innovation can also be an incremental novelty, e.g. the adoption of a new energy saving technology. Secondly, the emphasis is on results (in contrast to motivation). Thus it does not matter if environmental improvements have been the primary goal of a new product or process but whether an innovation produced positive environmental impacts. And finally, it must be environmentally beneficial compared to relevant (i.e. conventional) alternatives, e.g. energy saving light bulbs compared to conventional bulbs.

In this study, we largely follow the definitions given above, though focussing on technological innovations (i.e. product and process innovations) and ignoring pure organisational and marketing innovations. One reason is simply that our empirical data do not cover organisational and marketing innovations. But even if they would, there is good reason to focus on technological innovation since we are interested in the link between environmental regulation 
and innovation, and most regulations in this policy field target product characteristics and production processes.

\subsection{Environmental regulation}

We understand environmental regulation as government legislation (laws, acts, directives) as well as standards and industry commitments that contribute to reducing the burden on the environment and resource consumption. Environmental regulations can stimulate innovation activities of firms mainly through four channels. First, such regulation encourages providers of environmental goods and technologies (including environmental services) to develop product innovations in environmental processes. This is the case particularly if the state of the art is not sufficient to comply with regulations, thus necessitating the technological development of new products and the enhancement of existing ones. Since the introduction or modification of environmental regulation changes the conditions for economic activities, firms may see it as an opportunity to offer new products or services which help other firms to cope with these changed conditions. This is where innovations in the service sector come into play. The introduction of a mandatory deposit for disposable packaging could, for instance, lead to the provision of new logistics services which help retailers to deal with returned packaging.

Secondly, environmental regulation facilitates the development of new products in the field of product-integrated environmental protection. This may apply to requirements regarding the use or non-use of certain materials, dangerous substances or other product properties (such as recyclability, biodegradability, higher energy efficiency or a reduction in air, wastewater and noise emissions). Thirdly, environmental regulation stimulates investment activities which go beyond the mere implementation of environmental technologies in order to comply with these standards. These activities can lead to the firm-specific development of new or noticeably improved procedures in the field of process-integrated environmental protection, which aim at rationalisation or quality improvements in a broader sense. Finally, environmental regulation stimulates the development of new services which are aimed at counselling firms in environmental issues. This applies, for instance, to environmental advisors, who are concerned with environmental certifications or the assessment of environmental policies. New regulations may facilitate the development of new services. 


\subsection{The impact of environmental regulation on innovation}

To date, the literature on the relationship between environmental policy and technological change has mainly focused on the choice of an optimal policy instrument to induce environmental innovations (Jaffe et al., 2002). Concerning innovation specifically, the superiority of market-based instruments like taxes and tradable permits has long been the basic tenet in environmental economics. These instruments have been identified as environmental policy instruments with the highest dynamic efficiency (innovation efficiency). Their advantage is that they give permanent incentives for further, cost-efficient emissions reductions. They are also more cost-efficient (Rennings, 2000).

However, the analysis and comparison of single policy instruments certainly has its limitations, as in most cases several instruments from several policy areas affect innovation decisions simultaneously, and regulation, among many others, is only one factor affecting innovation decisions (Arundel and Kemp, 2009). Against this background, Blazejczak et al. (1999) berate "instrumentalism" in environmental policy, i.e., the assumption that the choice of policy instruments determines the policy success. According to their criticism, specific instruments as such (taxes, permits) are typically being overestimated in the discussion while important elements of successful environmental policy are not fittingly accounted for, as there are long-term goals and targets, the mix of instruments, different policy styles and actor constellations.

Regulation has also been identified as an important determinant of environmental innovation (together with factors of technology push, market pull and firm-specific factors with marketpull, technology-push and company specific factors) in the analysis of innovation surveys and is known as the "regulatory push/pull effect" (Rennings, 2000). While regulation seems still necessary to overcome the double externality problem, it is argued that also consumers can drive innovations (van den Bergh, 2008). Moreover, supply factors play an important role. Concerning the decision of where to locate $R \& D$ units, supply factors such as the access to local scientific and technological resources have gained increasing importance over the past years (Horbach, 2008). And also company specific factors influence the innovation decision, such as knowledge transfer mechanisms and involvement in networks (Rehfeld et al., 2007). It can be concluded that a complexity of technology push, market pull, policy and company specific factors influence the innovation decision of firms (Horbach, 2008). 
Against this background, the focus of this paper is especially on the regulatory push/pull effect which has been confirmed by several case studies and surveys, the latter including Green (1994), Cleff and Rennings (1999), Rennings and Zwick (2002), Brunnermeier and Cohen (2003) and Horbach (2008). Recently, Popp (2006) found evidence in a study with patent data from the United States, Japan and Germany that the innovation decisions of firms were mainly driven by national regulation, not by regulation abroad. Del Rio Gonzalez (2005) identified regulation pressure and corporate image as the main drivers of adopting cleaner technology in the Spanish pulp and paper industry. Frondel et al. (2007) find that, generally, policy stringency is an increasingly important driving force for environmental innovations rather than the choice of single policy instruments. Arimura et al. (2007) find the same empirical evidence for the effect of regulation on green R\&D, i.e., that stringency of environmental policy stimulates green $R \& D$ rather than the choice of a certain policy instrument. Facilities facing very stringent environmental regulation are more likely to conduct environmental R\&D.

Thus, environmental innovations are, in contrast to such technologies as microelectronics and telecommunications, normally not self-enforcing. Since factors of technology push and market pull alone do not seem to be strong enough, environmental innovations need specific regulatory support. Kammerer (2009) has shown that the innovation effects of regulation vary over different environmental issues of firms. Thus it should be distinguished between different innovation fields, e.g. toxic substances, low carbon, water technologies or recycling activities. stry of Environment sees especially potential for becoming lead markets in the future.

In this paper, we want to contribute to the literature by taking up Kammerer's argument of innovations being a response to regulation in a specific area. We will distinguish between power generation, resource and material efficiency, waste and recycling, sustainable mobility, air quality management, energy efficiency and sustainable water management. We want to show the impacts that regulation has in the different fields on innovation and on the economic performance of firms. And we are not only interested if a certain environmental innovation has been induced, but we will also analyse how far the respective environmental innovation has contributed to the success of the firm. 


\section{Data}

\subsection{The Mannheim Innovation Panel}

In this paper, we use firm-level data from the Mannheim Innovation Panel (MIP) to analyse the impact of regulation-driven environmental innovations on innovation success and firm performance. The MIP surveys innovation activities of firms from Germany on an annual base. The MIP is the German contribution to the Community Innovation Survey (CIS) of the European Commission and applies the recommendations of the OECD’s Oslo Manual on collecting innovation data (OECD and Eurostat, 2005) as well as Eurostat's methodological recommendations for CIS (see Janz et al., 2001; Peters, 2008). The MIP is a stratified random sample (stratified by sector, size and region) of enterprises with 5 of more employees in mining, manufacturing, construction and a wide area of service sectors. The panel sample is refreshed biannually to account for panel mortality. We use the 2003 survey which contained a set of questions on external sources that may have triggered firms' innovations, distinguishing five sources: customers/demand, competitors, suppliers, public science, and laws/regulations. Innovating firms were asked to indicate whether at least one product or process innovation introduced in the time period 2000-2002 were driven by the corresponding source, including an estimate of the sales share of new products in 2002 that can be attributed to the respective source. Firms stating that some of their innovations were triggered by regulations, were asked to name the precise law or regulation in a free text field. The question about the innovation source "law/regulation" is depicted in figure 1.

Innovations driven by environmental regulation were identified by analysing these responses and classifying them by policy fields. For regulations in the field of environmental policy, responses were assigned to subfields of environment policy based (including emission protection), energy, materials/dangerous substances, water, waste, noise. In some cases, it is possible that regulations with regard to environmental protection could not be identified - this applies to specifications concerning industry-specific regulations (which may also be related to environmental protection) as well as to specifications concerning standards and rules in general.

The MIP 2003 survey targeted a total sample of 22,435 firms. 4,538 firms provided full response to a 16-page mail questionnaire, which corresponds to a response rate of 20.2 percent. In order to control for a likely bias in innovation activities between responding and non- 
responding firms, a stratified random sample of non-responding firms were asked about their innovation activities through a short telephone survey. A total of 3,857 participated in this non-response survey (which is about 80 percent of the non-response sample). The results of this survey were used to calculate adjusted weights for the responding firms in the main survey so that the weighted sample of responding firms accurately represent the population of innovating and non-innovating firms in each strata.

Figure 1: Question on "laws and regulation" as a source of innovation

\subsection{Laws and Regulations as Innovation Sources}

Were any of the new or significantly improved products/services or processes introduced during 2000-2002 by your enterprise (as per question 1.2) innovations initiated because of new legal regulations (e.g. environmental legislation, technical standards) or other regulations (including voluntary commitment)?

No

Yes, product/service innovations .....

Yes, process innovation

Which laws and/or regulations (e.g. environmental legislation, labour law, technical standards, voluntary commitment of industry) were decisive for these innovations? Please list the names of the laws/regulations in order of significance.

Source: ZEW: Mannheim Innovation Panel, survey 2003.

\subsection{Regulations driving environmental innovation}

Out of the 4,538 responding firms, 2,415 did introduce product or process innovation during 2000 to 2002. These firms were asked on likely external sources of their innovations, including regulations. 461 firms stated that at least some of their innovations were triggered by regulation. 371 provided details on the specific laws, directives or other types of regulations. An analysis of the texts shows that 199 firms introduced innovations that were driven by environmental regulations, mentioning a total of 210 different regulations. Note that because of the reference period only environmental regulations introduced by 2002 could be mentioned. Since a considerable amount of time may pass from the introduction of a regulation until the innovation incentives included in it are marketable, the innovations driven by environmental regulation that are listed here are probably based on the state of environmental policy of the late 1990s up until approximately 2001 (that is, including the first years of the red-green coa- 
lition government of the Social Democrats and the Green Party in Germany from 1998 to 2005). The 210 different entries were assigned to seven areas of environmental policy:

- Power generation (12 percent of all entries) includes the EEG (Renewable Energy Sources Act), the KWKG (Heat-Power Cogeneration Act) and the EnWG (Energy Industry Act).

- Resource and material efficiency and avoiding dangerous substances (12 percent of all entries) primarily includes regulations concerning the prohibition or reduction of the use of substances such as lead, mercury, sulphur, CFCs, solvents, surfactants etc. were mentioned.

- $\quad$ Recycling and waste management (10 percent of all entries) covers the TASi (Technical Instruction on Municipal Waste), the AltFzgG (End-of-Life Vehicles Act) and the VerpackV (Packaging Directive).

- Air quality management, immission control (8 percent of all entries) includes the BImSchG (Federal Immission Control Act), the TA Luft (Technical Instruction on Air Quality Control) and several exhaust emission standards.

- Sustainable mobility (8 percent of all entries) refers to regulations such as the Environmental Tax Scheme (i.e. a separate tax on fuels) and the Traffic Noise Control Act as well as to car manufacturers mentioning regulations related to low-emission vehicles and parts of BImSchG and TA Luft related to the transport sector.

- Energy efficiency (7 percent of all entries) covers two regulaitons, the EnEV (Energysaving Directive) and the WSVO (Directive on Thermal Insulation).

- Sustainable water management (6 percent of all entries) refers the EU Water Framework Directive and the German Drinking Water Directive as well as to wastewater management directives adopted by various Federal States.

87 firms did not provide information on the source of regulation detailed enough to identify the field of environmental policy that has triggered their environmental innovations. Most of these firms simply stated that “environmental legislation” stimulated their innovations.

Remarkably, many firms mentioned regulations in the field of air quality management and immission control which does not appear among the priority fields of current environmental 
policy in Germany but was a policy priority in the 1990s. A main focus of this policy was to reduce harmful emissions by modernising plants and introducing end-of-pipe air pollution control measures through instruments such as the TA Luft and the BImSchG. Apparently, this policy has stimulated the introduction of product and process innovations until the early 2000s. The instruments also positively influenced innovation activities in the field of activity of "sustainable mobility". Between 2000 and 2002, TA Luft and BImSchG were the key driving forces for the introduction of environmentally efficient transport technologies in Germany.

Two important areas of current regulative activity in German environmental policy were not mentioned, namely regulations on likely environmental impacts on bio- and nanotechnology. This is not surprising since until 2002 no explicit regulations in these areas have been implemented. In the field of resource and material efficiency firms almost exclusively mentioned regulations which are aimed at avoiding certain toxic or otherwise harmful substances in materials and products or in the context of production processes.

\subsection{Sector distribution of regulation-driven environmental innovation}

The majority of innovations induced by environmental regulation were product innovations (82 percent of all firms with innovations driven by environmental regulation) while 31 percent introduced process innovations. 15 percent of firms with innovations triggered by environmental regulations did introduce both product and process innovations. The only field of environmental policy with a high share of process innovators is sustainable mobility. Many innovations in this field were introduced by firms from the transport sector who introduced new vehicles or new process technologies (route planners, information systems etc.) in order to provide their transport services in a more environmentally efficient way.

In the energy sector (power generation, energy efficiency), environmental regulations between 2000 and 2002 largely stimulated product innovations. One the one hand, these innovators come from utility suppliers that newly introduced "green electricity" into their product range. On the other hand, producers of machinery and equipment as well as engineering services developed or improved new technologies in the field of regenerative energy production or introduced corresponding services.

In order to elicit the sector distribution of innovations induced by environmental regulation, firm responses were weighted to represent the total firm population covered by the German 
innovation survey, taking into account disproportional sampling by sector, size class and region as well as differences in response rates and likely biases in innovation activities between responding and non-responding firms. Table 1 reports the (extrapolated) absolute number of firms with regulation-driven environmental innovations by sector, their share in a sector's total number of firms and total number of innovators, respectively, as well as a sector's share in the total number of firms with regulation-driven environmental innovations. The largest share of firms that introduced innovations motivated by environmental regulation. All figures refer to innovation activities in 2000 to 2002. In this period, a total of roughly 12,000 firms in Germany introduced environmental innovations triggered by regulation. This figure equals 2 percent of the total firm population surveyed by the innovation survey, and 5.6 percent of all innovators.

Table 1: Sector distribution of regulation-driven environmental innovators in Germany 2000-2002

Sector
Regulation-driven environmental innovators absolute as a percent- as a percent- as a percentnumber of age of all firms firms in the sector age of all innovators in the sector

\begin{tabular}{lrrrr} 
& & & innovations \\
\hline Manuf. of chemicals, pharmaceuticals & 300 & 13.0 & 16.0 & 2.5 \\
Engineering services, R\&D & 2,550 & 11.3 & 18.1 & 21.2 \\
Manuf. of machinery and equipment & 680 & 8.0 & 11.4 & 5.6 \\
Real estate, renting & 1,000 & 7.0 & 18.7 & 8.3 \\
Energy and water supply & 130 & 6.8 & 27.1 & 1.1 \\
Other business services, waste disposal & 1,170 & 5.9 & 18.5 & 9.7 \\
Manuf. of vehicles & 80 & 5.3 & 7.4 & 0.7 \\
Manuf. of electronics/electrical equipment & 200 & 4.8 & 6.1 & 1.7 \\
Manuf. of wood, paper; printing, publishing & 480 & 4.7 & 10.1 & 4.0 \\
Manuf. of metals and metal products & 540 & 4.5 & 8.6 & 4.5 \\
Manuf. of textiles, clothing, leather & 130 & 4.2 & 7.0 & 1.1 \\
Manuf. of rubber and plastics products & 170 & 3.8 & 6.3 & 1.4 \\
Manuf. of instruments & 100 & 3.3 & 4.7 & 0.8 \\
Manuf. of furniture, sports goods, games etc. & 60 & 2.0 & 3.7 & 0.5 \\
Mining and quarrying & 20 & 1.9 & 6.2 & 0.2 \\
Consulting, advertising & 860 & 1.8 & 3.8 & 7.1 \\
Financial intermediation & 80 & 1.6 & 3.4 & 0.7 \\
Transport, postal services & 590 & 1.5 & 4.9 & 4.9 \\
Manuf. of glass, ceramics, concrete & 40 & 1.5 & 3.7 & 0.3 \\
Construction & 1,890 & 1.4 & 5.4 & 15.7 \\
Manuf. of food, beverages, tobacco & 70 & 1.3 & 2.6 & 0.6 \\
Retail trade & 870 & 0.7 & 2.0 & 7.2 \\
Software, computing, telecommunications & 30 & 0.3 & 0.5 & 0.2 \\
Wholesale trade & 0 & 0.0 & 0.0 & 0.0 \\
\hline All sectors & 12,040 & 2.0 & 5.6 & 100.0 \\
\hline
\end{tabular}


Note: Firms in Germany having at least 5 employees in NACE (rev. 1.2) 10-41, 51- 60-67, 72-74, 90. All figures are extrapolated to the total firm population in Germany.

Source: ZEW: Mannheim Innovation Panel, survey 2003.

Sectors with high absolute numbers of regulation-driven environmental innovators are engineering services (including R\&D services), construction, other business services (including waste disposal), real estate and renting (including car rental), consulting and advertising services, and retail trade. The highest share of firms with innovations triggered by environmental regulation can be found in the chemicals and pharmaceuticals industry (13 percent of all firms). Energy and water supply is the sector where environmental regulation is particularly relevant to the sector's innovation activities, revealed by a 27 percent share of environmental innovators triggered by regulation in the total number of innovators in this sector. Other sectors strongly affected by environmental regulation in their innovation activities are real estate, other business services (including waste disposal) and engineering services.

\section{Impact of regulation-driven environmental innovations on innovation success}

\subsection{Empirical model}

In this section, we analyse whether firms with innovations that have been initiated by environmental regulations are able to achieve a similar innovation success compared to other innovators. For this purpose, we distinguish three indicators for innovation success. With product innovation, the share of sales generated by market novelties should capture the ability of firms to develop and successfully market new products and services prior to any competitor. As a second indicator - the share of sales generated by "product-range novelties"- captures a different dimension of novelty, i.e. whether new products have no predecessors in the innovating firm and thus enlarge a firm's product portfolio (and most likely the group of customers addressed by a firm's products and services). Note that market novelties and productrange novelties may overlap, i.e. a firm may introduce a product which is both new-to-themarket and at the same time expands the firm's product portfolio. With process innovations, we use the share of unit costs that has been reduced by new or improved process technology. Each success indicator refers to the economic results achieved in 2002 with innovations introduced during 2000 and 2002. 
Determinants of innovations success are estimated by a two stage procedure. In the first stage, we model the determinants of an innovating firm's ability to achieve a certain level of innovation success ( ${ }^{\mathrm{m}} \mathrm{INS}, m$ indicating the innovation success indicator), which is the novelty of product innovations (market novelties-MN, product-range novelties-PN) and the ability to achieve unit cost reductions for process innovations (CO). The models are restricted to firms that have introduced the respective type $\mathrm{k}$ of innovation $\left({ }^{\mathrm{k}} \mathrm{INN}\right)$ which is product innovations (PD) in case of MN and PN, and process innovations (PC) in case of CO. Note that not all product innovators are able to introduce market or product-range novelties. In fact most product innovators introduce new products that do not qualify for any of the two types of novelties (see Rammer et al., 2009). These non-novel product innovations are typically imitations of products that have been introduced by competitors before and which substitute older products within a firm's existing product portfolio. With regard to process innovations, only about every second process innovator realises cost savings. Other process innovators rather focus on quality aspects or implement new processes to enabling the production of new products. There is also a relevant fraction of process innovators that do aim at cost reductions but were not able to achieve significant savings.

In the second stage, we model the determinants of the size of the economic returns generated by $\mathrm{MN}, \mathrm{PN}$ and $\mathrm{CO}$, provided that a firm has introduced the respective type of innovation, through three separate models. Dependent variables are the sales share with market novelties $(\mathrm{SM})$, the sales share with product-range novelties (SN), and the share of unit costs reduced through process innovation (RC). Step contains the estimated residual from the first stage model $\left({ }^{\mathrm{m}} \lambda^{*}\right)$.

Our two-step innovation success model reads as follows:

$$
\begin{aligned}
&{ }^{\mathrm{m}} \mathrm{INS}_{\mathrm{i}}={ }^{\mathrm{m}} \boldsymbol{\alpha}_{0}+{ }^{\mathrm{m}} \boldsymbol{\alpha}_{1} \mathbf{X}_{\mathrm{i}}+{ }^{\mathrm{m}} \boldsymbol{\alpha}_{2}{ }^{\mathrm{m}} \mathbf{I S}_{\mathrm{i}}+{ }^{\mathrm{m}} \varepsilon_{\mathrm{i}} \quad \text { for }{ }^{\mathrm{k}} \mathrm{INN}>0 \\
& \mathrm{~m} \in\{\mathrm{MN}, \mathrm{PN}, \mathrm{CO}\}, \mathrm{k}=\mathrm{PD} \text { for } \mathrm{m} \in\{\mathrm{MN}, \mathrm{PN}\} ; \mathrm{k}=\mathrm{PC} \text { of } \mathrm{m}=\mathrm{CO} \\
&{ }^{\mathrm{n}} \mathrm{SUC}_{\mathrm{i}}={ }^{\mathrm{n}} \beta_{0}+{ }^{\mathrm{n}} \boldsymbol{\beta}_{1}{ }^{\mathrm{n}} \mathbf{Y}_{\mathrm{i}}+{ }^{\mathrm{n}} \boldsymbol{\beta}_{2}{ }^{\mathrm{n}} \mathbf{I} \mathbf{S}_{\mathrm{i}}+{ }^{\mathrm{m}} \beta_{3}{ }^{\mathrm{m}} \lambda_{\mathrm{i}}+{ }^{\mathrm{n}} \varepsilon_{\mathrm{i}} \quad \text { for }{ }^{\mathrm{m}} \mathrm{INS}>0 \\
& \text { for } \mathrm{n} \in\{\mathrm{SM}, \mathrm{SP}, \mathrm{RC}\} ; \mathrm{m}=\mathrm{MN} \text { for } \mathrm{n}=\mathrm{SM}, \mathrm{m}=\mathrm{PN} \text { for } \mathrm{n}=\mathrm{SP}, \mathrm{m}=\mathrm{CO} \text { for } \mathrm{n}=\mathrm{RC}
\end{aligned}
$$

Equations [1] and [2] are estimated using a Heckman two-step selection model (see Heckman, 1979). In addition, we consider a model variant that merges both equations into one which is estimated for all product and process innovators, respectively. Since the innovation success 
variable in this model is left-censored (e.g. for all product innovators that did not introduce a market novelty, SUC is zero), we use a Tobit model to estimate [3]:

$$
\begin{aligned}
&{ }^{\mathrm{n}} \mathrm{SUC}_{\mathrm{i}}={ }^{\mathrm{n}} \chi_{0}+{ }^{\mathrm{n}} \chi_{2}{ }^{\mathrm{n}} \mathbf{W}_{\mathrm{i}}+{ }^{\mathrm{n}} \chi_{3}{ }^{\mathrm{n}} \mathbf{I} \mathbf{S}_{\mathrm{i}}+{ }^{\mathrm{n}} \varepsilon_{\mathrm{i}} \quad \text { for }{ }^{\mathrm{k}} \mathrm{INN}>0 \\
& \text { for } \mathrm{n}=\{\mathrm{SM}, \mathrm{SP}, \mathrm{RC}\} ; \mathrm{m}=\mathrm{MN} \text { for } \mathrm{n}=\mathrm{SM}, \mathrm{m}=\mathrm{PN} \text { for } \mathrm{n}=\mathrm{SP}, \mathrm{m}=\mathrm{CO} \text { for } \mathrm{n}=\mathrm{RC} ; \\
& \mathrm{k}=\mathrm{PD} \text { for } \mathrm{m}=\{\mathrm{MN}, \mathrm{PN}\}, \mathrm{k}=\mathrm{PC} \text { for } \mathrm{m}=\mathrm{CO}
\end{aligned}
$$

The Heckman selection models [2] and [3] contain vectors of explanatory variables ( $\mathbf{X}$ and $\mathbf{Y}$, respectively) which alter in some respect. $\mathbf{X}$ includes firm size (log of number of employees at full-time equivalents -SIZE) and human capital (share of graduated employees -HUC) as well as two indicators for R\&D activities (one for continuous R\&D -RDC- and one for occasional R\&D -RDO) and an indicator for innovation cooperation (i.e. whether a firm did actively cooperate with other firms or public institutions such as universities in developing innovations -COOP). We also consider dummies for a firm's location (East vs. West Germany -EAST) and sector affiliation (24 aggregated 2-digit sector groupings -IND1 to IND24) as controls. COOP serves as instrument, i.e. this variable exerts a statistically significant influence on the probability to introduce market novelties, product-range novelties or cost reducing process innovations, respectively, but has no significant impact on the respective success variable (share in sales, share of unit cost reduction) in the second stage equations.

$\mathbf{Y}$ includes SIZE, innovation expenditure as a share in sales (measuring the resources a firm devotes to innovative activities -IES) as well as indicators for regional and sector affiliation. In addition, $\mathbf{Y}$ includes a dummy for process innovation (for models on product innovation success) and product innovation (for models on process innovation success), respectively, in order to take into account that in firms with both product and process innovations IES is devoted to both innovation types. In model [3], the vector $\mathbf{W}$ comprises all variables from vectors $\mathbf{X}$ and $\mathbf{Y}$.

The key variable in our models is a vector for the sources that triggered innovation (IS). This vector contains a set of dummies indicating whether a firm stated that customers (IS_CS), suppliers (IS_SP), competitors (IS_CP), public science (IS_SC) or regulations provided essential impulses for their product or process innovations. Regulation as innovation source is differentiated by environmental regulations (IS_ER) and non-environmental regulations (IS_OR). Since some firms that indicated regulation-driven innovations did not specify the type of regulation we cannot determine whether environmental or non-environmental regulations were the drivers. These firms are represented by a separate indicator for unknown regu- 
lation sources (IS_UR). In order to analyse likely variations in the effects of IS_ER by field of environmental policy, we further differentiate environmental regulations as a source of innovation by seven policy fields (power generation, resource and material efficiency, recycling management, sustainable mobility, air quality management, energy efficiency, water management -IS_ER1 to IS_ER7) and an eight category for those firms triggered by environmental regulation that did not state any specific legislation (IS_ER8). A further dummy indicates firms that did not use any external innovation sources (NOIS). All sources are measured specific to product and process innovation.

All Data on model variables are taken from the 2003 wave of the MIP and directly refer to respective survey questions. Detailed descriptive information on this survey wave can be found in Rammer et al. (2005). Table A1 in the Appendix provides descriptive statistics for all model variables.

\subsection{Estimation results}

Table 2 presents the estimation results of twostep Heckman selection models on the impact of regulation-driven environmental innovations (IS_ER) on product and process innovation success. The models have been estimated using the programme package Stata 10.0. We find a statistically significant negative impact of such innovations on the probability to introduce market novelties, while there is no impact on the share of sales generated by market novelties within the group of firms that managed to introduce such innovations onto the market. For product-range novelties and for cost reducing process innovations, we find no overall effect of regulation-driven environmental innovations, neither on the probability to introduce theses types of innovations nor on the magnitude of economic effects.

When looking at the different fields of environmental policy that triggered innovations, we see that the negative impact on introducing market novelties originates from regulations in the field of power generation and - to a lesser extent - water management. There is also a small negative impact for regulation-driven environmental innovators that did not mention the respective regulation in detail. Firms introducing new products triggered by these regulations -which include incentives for producing energy based on renewable technologies or provisions to provide higher-quality drinking water- often adopt innovations already introduced by others before and only rarely develop entirely new products. This implies that regulations in these two fields tend to stimulate adaptive product innovations which rely on established technologies, at least in the period under cover (2000-2002). This result can be linked to a 
rapid diffusion of renewable energy technologies in the early 2000s, following some policy shift from 1999 onwards after the new coalition of the social democrats and the green party took over governmental power at the Federal level. For all other fields of environmental policy, no statistically significant negative impacts on the propensity of firms to introduce market novelties can be found. In contrast, regulations in the field of sustainable mobility (which are particularly related to lower emissions of vehicles) stimulated innovations which were able to achieve above average sales shares. This reflects a high propensity of demand to accept "green innovations" in the vehicle sector. It also reveals that German vehicle producers tend to owe some competitive advantages in marketing such innovations. Since most of these innovations originate from the car industry, this result is in line with findings on Germany's lead market position in this particular market (see Beise and Cleff, 2004; Beise and Rammer, 2006).

Table 2: Impact of environmental regulations as a source for innovation on innovation success: estimation results (marginal effects) of Heckman selection models

\begin{tabular}{|c|c|c|c|c|c|c|c|c|c|}
\hline \multirow{3}{*}{$\begin{array}{l}\text { Introduction of novelties/cost } \\
\text { reduction (yes/no) } \\
\text { IS_ER }^{\text {b) }}\end{array}$} & \multicolumn{3}{|c|}{$\mathrm{MN}$} & \multicolumn{3}{|c|}{ PN } & \multicolumn{3}{|c|}{$\mathrm{CO}$} \\
\hline & \multirow{2}{*}{$\begin{array}{r}\text { M.E. } \\
-0.117\end{array}$} & \multicolumn{2}{|c|}{ t-value } & \multirow{2}{*}{$\begin{array}{r}\text { M.E. } \\
-0.033\end{array}$} & \multicolumn{2}{|c|}{ t-value } & \multirow{2}{*}{$\begin{array}{r}\text { M.E. } \\
0.032\end{array}$} & \multicolumn{2}{|c|}{ t-value } \\
\hline & & -2.33 & $* *$ & & -1.10 & & & 0.08 & \\
\hline IS_ER1 (air quality) & 0.142 & 0.71 & & 0.233 & 1.28 & & 0.123 & 0.47 & \\
\hline IS_ER2 (power generation) & -0.323 & -2.58 & $* *$ & -0.130 & -0.96 & & 0.322 & 1.52 & \\
\hline IS_ER3 (resource efficiency) & 0.130 & 0.91 & & -0.120 & -0.85 & & 0.088 & 0.35 & \\
\hline IS_ER4 (recycling, waste) & 0.045 & 0.31 & & 0.082 & 0.57 & & -0.385 & -1.37 & \\
\hline IS_ER5 (water management) & -0.270 & -1.79 & $*$ & 0.009 & 0.04 & & a) & & \\
\hline IS_ER6 (sustainable mobility) & 0.153 & 0.92 & & 0.097 & 0.56 & & a) & & \\
\hline IS_ER7 (energy efficiency) & -0.173 & -0.99 & & -0.157 & -0.83 & & -0.014 & -0.04 & \\
\hline IS_ER8 (unspecified) & -0.129 & -1.77 & $*$ & -0.114 & -1.59 & & -0.097 & -0.78 & \\
\hline IS_OR & -0.049 & -1.02 & & 0.030 & 0.65 & & 0.023 & 0.27 & \\
\hline IS_UR & -0.015 & -0.20 & & 0.019 & 0.25 & & 0.227 & 1.55 & \\
\hline IS_CS & 0.052 & 1.24 & & 0.019 & 0.46 & & 0.054 & 0.95 & \\
\hline IS_SP & 0.000 & -0.01 & & -0.031 & -0.85 & & 0.126 & 2.13 & $* *$ \\
\hline IS_CP & -0.070 & -2.08 & $* *$ & 0.001 & 0.02 & & -0.068 & -1.13 & \\
\hline IS_SC & 0.122 & 2.87 & $* * *$ & 0.094 & 2.25 & $* *$ & 0.063 & 0.92 & \\
\hline NOIS & -0.026 & -0.49 & & -0.033 & -0.64 & & 0.088 & 1.40 & \\
\hline SIZE & -0.041 & -1.42 & & -0.090 & -2.98 & $* * *$ & 0.042 & 4.27 & $* * *$ \\
\hline SIZE2 & 0.004 & 1.56 & & 0.008 & 2.86 & $* * *$ & & & \\
\hline RDC & 0.119 & 3.22 & $* * *$ & 0.031 & 0.83 & & 0.042 & 0.97 & \\
\hline RDO & -0.003 & -0.07 & & -0.022 & -0.48 & & 0.076 & 1.47 & \\
\hline HUC & 0.087 & 1.27 & & 0.044 & 0.64 & & -0.081 & -0.98 & \\
\hline COOP & 0.087 & 2.84 & $* * *$ & 0.095 & 3.12 & $* * *$ & -0.078 & -2.22 & $* *$ \\
\hline EAST & -0.121 & -3.86 & $* * *$ & 0.014 & 0.46 & & -0.064 & -1.75 & $*$ \\
\hline \multirow{2}{*}{$\begin{array}{l}\text { Economic success with novel- } \\
\text { ties/cost reductions (share) }\end{array}$} & \multicolumn{3}{|c|}{ SM } & \multicolumn{3}{|c|}{ SP } & \multicolumn{3}{|c|}{$\mathrm{RC}$} \\
\hline & M.E. & \multicolumn{2}{|c|}{$\mathrm{t}$-value } & M.E. & \multicolumn{2}{|c|}{ t-value } & M.E. & \multicolumn{2}{|c|}{ t-value } \\
\hline $\mathrm{IS}_{\mathrm{N}} \mathrm{ER}^{\mathrm{b})}$ & 0.041 & \multicolumn{2}{|c|}{1.34} & -0.033 & \multicolumn{2}{|c|}{-1.10} & -0.006 & \multicolumn{2}{|c|}{-0.30} \\
\hline IS_ER1 (air quality) & -0.088 & \multicolumn{2}{|l|}{-0.85} & -0.025 & \multicolumn{2}{|l|}{-0.26} & 0.022 & \multicolumn{2}{|l|}{0.40} \\
\hline IS_ER2 (power generation) & -0.016 & \multicolumn{2}{|l|}{-0.16} & 0.018 & \multicolumn{2}{|l|}{0.20} & 0.037 & \multicolumn{2}{|l|}{0.37} \\
\hline IS_ER3 (resource efficiency) & 0.009 & \multicolumn{2}{|l|}{0.13} & 0.069 & \multicolumn{2}{|l|}{0.83} & -0.039 & -0.79 & \\
\hline IS_ER4 (recycling, waste) & -0.009 & -0.10 & & -0.036 & -0.44 & & 0.007 & 0.07 & \\
\hline IS_ER5 (water management) & -0.081 & -0.73 & & -0.103 & -1.19 & & 0.024 & 0.29 & \\
\hline
\end{tabular}




\begin{tabular}{|c|c|c|c|c|c|c|c|c|c|}
\hline IS_ER6 (sustainable mobility) & 0.249 & 2.64 & $* * *$ & 0.101 & 0.94 & & 0.005 & 0.07 & \\
\hline IS_ER7 (energy efficiency) & 0.111 & 0.90 & & -0.038 & -0.25 & & 0.052 & 0.83 & \\
\hline IS_ER8 (unspecified) & 0.035 & 0.79 & & -0.078 & -1.74 & $*$ & -0.074 & -2.12 & $* *$ \\
\hline IS_OR & 0.006 & 0.20 & & -0.043 & -1.60 & & 0.035 & 1.53 & \\
\hline IS_UR & 0.081 & 1.64 & & -0.005 & -0.12 & & 0.014 & 0.38 & \\
\hline IS_CS & 0.047 & 1.74 & $*$ & -0.051 & -2.00 & $* *$ & 0.026 & 1.85 & $*$ \\
\hline IS_SP & 0.006 & 0.26 & & 0.017 & 0.83 & & 0.038 & 2.14 & $* *$ \\
\hline IS_CP & -0.010 & -0.48 & & -0.007 & -0.35 & & 0.022 & 1.42 & \\
\hline IS_SC & -0.028 & -0.99 & & 0.020 & 0.72 & & 0.056 & 3.05 & $* * *$ \\
\hline NOIS & 0.029 & 0.88 & & -0.044 & -1.40 & & 0.029 & 1.70 & $*$ \\
\hline $\mathrm{PC}$ & 0.014 & 0.86 & & 0.034 & 2.00 & $*$ & & & \\
\hline PD & & & & & & & -0.001 & -0.13 & \\
\hline SIZE & -0.019 & -3.77 & $* * *$ & -0.027 & -5.43 & $* * *$ & -0.005 & -1.54 & \\
\hline IES & 0.129 & 9.50 & $* * *$ & 0.066 & 7.85 & $* * *$ & 0.046 & 4.83 & $* * *$ \\
\hline EAST & 0.025 & 1.22 & & 0.021 & 1.20 & & -0.024 & -2.35 & $* *$ \\
\hline$\lambda$ & -0.156 & -1.61 & & -0.112 & -0.17 & & 0.173 & 0.28 & \\
\hline Constant & 0.048 & 2.73 & $* * *$ & -0.046 & 3.81 & $* * *$ & -0.038 & 1.85 & * \\
\hline No. observations (uncensored) & 1,324 & (704) & & 1,318 & (702) & & 922 & (511) & \\
\hline Wald chi ${ }^{2}$ & 287.9 & $* * *$ & & 288.8 & $* * *$ & & 189.0 & $* * *$ & \\
\hline
\end{tabular}

$*, * *, * * *$ : statistically significant at the $10 \%, 5 \%, 1 \%$ level. M.E.: marginal effects.

a) All firms with innovation triggered by environmental regulations in the fields of water management and sustainable mobility introduced cost reducing process innovations.

b) Results from separate model estimations excluding IS_ER1 to IS_ER8.

All models include 24 industry dummies which are jointly significant.

Source: ZEW: Mannheim Innovation Panel, survey 2003.

For market novelties and cost reducing process innovation, we find some negative effects on the economic success indicators for these two types of innovations in the group of firms that report regulation-driven environmental innovations, but did not name the regulation that actually provided the impetus. A positive impact on the probability to introduce cost reducing innovations is found for firms reporting regulation-driven process innovation, but did not specify which area of regulation triggered their innovative efforts. One may assume that a significant part of these firms' innovation is related to environmental regulations.

These results are largely confirmed when using a Tobit model instead of a two-stage model (see Table A2 in the Appendix for estimation results). Environmental innovators triggered by regulations in the field of sustainable mobility yield significantly higher sales shares with market novelties also when considering all product innovators without any market novelties. In contrast, environmental innovators triggered by regulations in the field of water management generate significantly smaller sales share with products that were new to their markets. With the share of sales originating from product-range novelties as well as with the share of unit costs reduced by process innovations, only the group of environmental innovators without specifying the concrete field of environmental policy show lower innovation success. 
When looking at the other sources of innovation, we find a strong positive impact of public science for a firm's probability to introduce market novelties or product-range novelties. In addition, process innovations based on new research findings from universities and government laboratories increase the share of unit cost reduction. The same is true for process innovation triggered by suppliers. Process innovators that use impulses from this source are also more likely to implement cost saving processes. Firms that use competitors as innovations source are less likely to introduce market novelties (indicating that they focus on adopting innovations from other firms in their market). Customers are a valuable innovation source for achieving higher sales shares with market novelties, pointing to the importance of customerspecific products for an early market success. Firms that refrain from using external sources for orienting their innovation activities do not achieve a higher or lower innovation success compared to firms relying on external impulses.

A further determinant of innovation success is size, exerting a u-shaped effect for the propensity to introduce market or product-range novelties, the inflection point being around 150 employees for market novelties and about 300 for product-range novelties and a negative effect on the sales share with these innovations (meaning that smaller firms are better capable to achieve higher sales shares with their novel products, which partly reflects their less disperse product portfolio compared to large firms). Continuous in-house R\&D activities clearly help to develop and introduce market novelties, as does cooperating with others, which is also a driver for introducing product-range novelties, but is not helpful for introducing cost reducing process innovations. With regard to the sales shares with novelties and the share of unit costs reduction, the volume of financial commitment to innovation has a strong positive impact.

\section{Impact of regulation-driven environmental innovations on firm per- formance}

\subsection{Empirical model}

This section is devoted to reveal likely impacts of regulation-driven environmental innovation on a firm's economic performance, i.e. its ability to generate profits. While our previous analysis has shown that there is no general negative impact of this type of innovation on a firm's innovation success, there still may be negative performance effects since regulationdriven innovations may result in higher innovation costs compared to other innovations e.g. due to more extensive compliance request, more complex technologies or additional approval 
requirements. One can also argue that regulation-driven environmental innovations may be associated with higher profits. The existence of regulation combined with regulation-related innovation activities gives environmental innovators the power to set prices for their customers since regulation can force customers to use certain types of goods or technology, which reduces price elasticity of demand. At the same time, innovation activities enable environmental innovators to achieve - unlike other providers - a higher level of product differentiation, which limits price competition and may raise profits.

We investigate the likely performance effects of regulation-driven environmental innovations by a simple firm performance model, using the price-cost margin (or profit margin) as key indicator for firm performance. As a starting point, we use the model developed by Czarnitzki and Kraft (2010) who used the very same data base. A firm's price-cost margin (PCM, i.e. sales less labour cost, capital cost and material cost as a share in sales) is a function of market structure, a firm's market share and a firm's prior investment in technology (see Czarnitzki and Kraft, 2010, for details as well as Geroski et al., 1993, and Grabowski and Mueller, 1978, for a more general discussion of how to model a firm's price-cost margin). We use the Herfindahl concentration index (HCI) measured at the 3-digit industry level as key market structure variable. Unfortunately, we do not have firm-specific market share information at hand. Czarnitzki and Kraft (2010) used a firm's sales in the total sales of the 3-digit industry sector in Germany the firm belongs to as a proxy for market share, but could not find any significant effect for this poor measure of market share (since 3-digit industries are much too broad to identify product markets, and market shares of exporting firms are overestimated when only using sales of domestic industry). We therefore omit this variable. Prior investment in technology is measured by the stock of patents $(\mathrm{PAT})^{2}$ as well as by past R\&D expenditure over sales (RDI). In line with Czarnitzki and Kraft (2010), we interact HCI and RDI in order to identify whether high R\&D investment is used to deviate in highly concentrated industry from collusive settlements.

Further controls represented in the vector $\mathbf{Z}$ of explanatory variables include export activity (EXP), a firm's age (logarithm of the number of years since firm foundation -AGE), a firm's

2 We use a perpetual inventory method to estimate the patent stock of firm $i$ in the year 2001, assuming linear depreciation over a 20 year period. We consider patent applications at the German Patent and Trademark Office as well as applications at the European Patent Office (including patents applied through the Patent Cooperation Treaty procedure). Firm-specific patent information was collected by matching the name of the firms participating in the innovation survey with the names of patent applicants using a special software developed at ZEW, and including an extensive manual double-check. Since most firms in our sample did never apply a patent -including almost all service firms- we add a 
size in the previous year (SIZE_L), capital-labour ratio (CLR) and whether a firm is foreignowned (FOR). We extend the innovation side of this model by adding innovation success variables (MN, PN, CO) since we assume that these variables are associated with higher innovation rents compared to other types of innovations. In addition, we add the full set of innovation source variables (IS). The model reads as follows:

$\mathrm{PCM}_{\mathrm{i}}=\chi_{0}+\chi_{1} \mathbf{Z}_{\mathrm{i}}+\chi_{2} \mathrm{MN}_{\mathrm{i}}+\chi_{3} \mathrm{PN}_{\mathrm{i}}+\chi_{4} \mathrm{CO}_{\mathrm{i}}+\chi_{5} \mathbf{I S}_{\mathrm{i}}+\varepsilon_{\mathrm{i}}$

The price-cost margin is measured in the innovation survey by seven categories in order to reduce the response burden and to increase the firms' willingness to provide this type of information, which is regarded as sensitive data by many firms. The seven categories are less than 0 percent, 0 to less than 2 percent, 2 to less than 4 percent, 4 to less than 7 percent, 7 to less than 10 percent, 10 to less than 15 percent, and 15 percent and more. ${ }^{3}$ We employ interval regressions with known thresholds to estimate [4]. The estimated coefficients of these models can be interpreted as elasticity.

All data for model variables are taken from the 2003 wave of the MIP except for PAT (see footnote above), HCI (which is reported by the Monopoly Commission of the federal government) and AGE, which is taken from the Creditreform data base which serves as sampling frame for the MIP and covers virtually all enterprises in Germany. Table A3 in the Appendix provides descriptive statistics for all variables used to estimate model [4].

\subsection{Estimation results}

The estimation results of model [4] are shown in Table 4. Two model versions were tested. One version includes innovation source variables without differentiating whether the innovation triggered by the respective source was a product or a process innovation. The second version does make this differentiation for all innovation sources. While we find no effect of environmental regulations as innovation source on the price-cost margin when considering product and process innovation sources together, differentiating by product and process innovation reveals that environmental process innovation triggered by regulations yield a lower profit margin. The size of this negative effect is quite remarkable. The profit margin falls by

dummy for firms with zero patents (NOPAT) and measure the stock of patents in logarithm (adding one patent for each firm).

3 A significant share of firms (19 percent) did not provide information on their price-cost margin. Czarnitzki and Kraft (2010) showed that the group of firms with item non-response does not significantly deviate form the group of responding firms with respect to main characteristics (size, sector, region, etc.) 
about 2 percentage points. When looking at the fields of environmental policy, it tends to be process innovators driven by regulations in sustainable mobility who perform worst. Process innovations based on sustainable mobility regulation often concern firms in transportation, logistics and other distribution services, many of them acting not only in the German market but in European and overseas markets. They are urged to modernise their vehicles in order to meet new regulatory requirements which increases their unit cost (e.g. through higher depreciation). At the same time, international competition is fierce, resulting in low price levels and decreasing price-cost margins for environmental innovators.

Table 4: Impact of environmental regulations as a source for innovation on innovation success: estimation results (marginal effects) of interval regression models

\begin{tabular}{|c|c|c|c|c|c|}
\hline \multirow[t]{2}{*}{ Introduction of novelties/cost reduction (yes/no) } & \multicolumn{2}{|c|}{ PCM (1) } & \multicolumn{3}{|c|}{ PCM (2) } \\
\hline & M.E. & t-value & M.E. & t-va & lue \\
\hline $\mathrm{IS}_{\mathrm{E}} \mathrm{R}^{\mathrm{a})}(\mathrm{PD}=1$ or $\mathrm{PC}=1)$ (air quality) & 0.470 & 0.86 & & & \\
\hline IS_ER1 (PD=1 or PC=1) (power generation) & -1.232 & -1.31 & & & \\
\hline IS_ER2 (PD=1 or PC=1) (resource efficiency) & 1.283 & 1.21 & & & \\
\hline IS_ER3 (PD=1 or PC=1) (recycling, waste) & 3.315 & 1.71 & & & \\
\hline IS_ER4 (PD=1 or PC=1) (water management) & 0.961 & 0.62 & & & \\
\hline IS_ER5 (PD=1 or $\mathrm{PC}=1$ ) (sustainable mobility) & -0.485 & -0.37 & & & \\
\hline IS_ER6 (PD=1 or PC=1) (energy efficiency) & -0.875 & -0.73 & & & \\
\hline IS_ER7 $(\mathrm{PD}=1$ or $\mathrm{PC}=1$ ) (unspecified) & -1.147 & -0.69 & & & \\
\hline IS_ER8 $(\mathrm{PD}=1$ or $\mathrm{PC}=1)$ & 0.028 & 0.03 & & & \\
\hline IS_OR (PD=1 or $\mathrm{PC}=1)$ & 0.520 & 0.90 & & & \\
\hline IS_UR (PD=1 or $\mathrm{PC}=1)$ & -1.018 & -1.25 & & & \\
\hline IS_CS $(\mathrm{PD}=1$ or $\mathrm{PC}=1)$ & -0.203 & -0.56 & & & \\
\hline IS_SP $(\mathrm{PD}=1$ or $\mathrm{PC}=1)$ & -0.530 & -1.36 & & & \\
\hline $\mathrm{IS} \_\mathrm{CP}(\mathrm{PD}=1$ or $\mathrm{PC}=1)$ & -0.146 & -0.27 & & & \\
\hline IS_SC $(\mathrm{PD}=1$ or $\mathrm{PC}=1)$ & 0.605 & 1.61 & & & \\
\hline NOIS $(\mathrm{PD}=1$ or $\mathrm{PC}=1)$ & -0.804 & -1.13 & & & \\
\hline $\mathrm{IS}_{-} \mathrm{ER}^{\mathrm{a})}(\mathrm{PD}=1)$ & & & 0.767 & 1.23 & \\
\hline IS_ER1 (PD=1) (air quality) & & & -0.752 & -0.97 & \\
\hline IS_ER2 (PD=1) (power generation) & & & 1.933 & 1.58 & \\
\hline IS_ER3 (PD=1) (resource efficiency) & & & 4.886 & 1.65 & $*$ \\
\hline IS_ER4 (PD=1) (recycling, waste) & & & 0.817 & 0.40 & \\
\hline IS_ER5 (PD=1) (water management) & & & -0.397 & -0.28 & \\
\hline IS_ER6 $(\mathrm{PD}=1)$ (sustainable mobility) & & & -0.275 & -0.22 & \\
\hline IS_ER7 (PD=1) (energy efficiency) & & & -1.103 & -0.47 & \\
\hline IS_ER8 (PD=1) (unspecified) & & & 0.592 & 0.56 & \\
\hline IS_OR $(\mathrm{PD}=1)$ & & & 0.451 & 0.71 & \\
\hline IS_UR (PD=1) & & & -1.829 & -1.93 & $*$ \\
\hline IS_CS (PD=1) & & & -0.135 & -0.36 & \\
\hline IS_SP $(P D=1)$ & & & -0.619 & -1.49 & \\
\hline IS_CP $(P D=1)$ & & & -0.252 & -0.43 & \\
\hline IS_SC $(P D=1)$ & & & 0.674 & 1.65 & $*$ \\
\hline NOIS $(\mathrm{PD}=1)$ & & & -0.289 & -0.60 & \\
\hline $\mathrm{IS}_{-} \mathrm{ER}^{\mathrm{a})}(\mathrm{PC}=1)$ & & & -2.046 & -2.31 & $* *$ \\
\hline IS_ER1 (PC=1) (air quality) & & & -1.692 & -0.65 & \\
\hline IS_ER2 (PC=1) (power generation) & & & -1.705 & -1.26 & \\
\hline IS_ER3 (PC=1) (resource efficiency) & & & -2.520 & -0.71 & \\
\hline IS_ER4 (PC=1) (recycling, waste) & & & 1.036 & 0.59 & \\
\hline IS_ER5 (PC=1) (water management) & & & -2.705 & -1.04 & \\
\hline IS_ER6 (PC=1) (sustainable mobility) & & & -3.983 & -1.81 & $*$ \\
\hline
\end{tabular}




\begin{tabular}{|c|c|c|c|c|c|c|}
\hline IS_ER7 (PC=1) (energy efficiency) & & & & -1.009 & -0.42 & \\
\hline IS_ER8 (PC=1) (unspecified) & & & & -2.184 & -1.48 & \\
\hline IS_OR (PC=1) & & & & 1.243 & 1.08 & \\
\hline IS_UR $(P C=1)$ & & & & 2.603 & 1.37 & \\
\hline IS_CS (PC=1) & & & & -0.678 & -1.23 & \\
\hline IS_SP (PC=1) & & & & 0.198 & 0.29 & \\
\hline IS_CP $(P C=1)$ & & & & -0.429 & -0.42 & \\
\hline IS_SC $(P C=1)$ & & & & -0.590 & -0.87 & \\
\hline NOIS $(P C=1)$ & & & & -0.566 & -1.35 & \\
\hline $\mathrm{MN}$ & 0.749 & 2.06 & $* *$ & 0.824 & 2.24 & $* *$ \\
\hline PN & -0.046 & -0.13 & & -0.002 & -0.01 & \\
\hline $\mathrm{CO}$ & 0.445 & 1.31 & & 0.806 & 1.92 & $*$ \\
\hline SIZE_L & -0.508 & -6.37 & $* * *$ & -0.487 & -6.09 & $* * *$ \\
\hline FOR & 1.033 & 2.19 & $* *$ & 0.995 & 2.11 & $* *$ \\
\hline EXP & 0.663 & 2.38 & $* *$ & 0.652 & 2.34 & $* *$ \\
\hline HCI & 0.005 & 3.38 & $* * *$ & 0.005 & 3.38 & $* * *$ \\
\hline RDI & 0.016 & 0.02 & & 0.036 & 0.05 & \\
\hline HCI_RDI & -0.027 & -0.89 & & -0.028 & -0.93 & \\
\hline PAT & 0.236 & 1.81 & $*$ & 0.226 & 1.72 & $*$ \\
\hline NOPAT & -0.049 & -0.12 & & -0.068 & -0.17 & \\
\hline CLR & -0.073 & -1.14 & & -0.055 & -0.77 & \\
\hline AGE & 0.222 & 1.81 & $*$ & 0.201 & 1.65 & $*$ \\
\hline EAST & -0.206 & -0.80 & & -0.190 & -0.74 & \\
\hline Constant & 3.974 & 5.29 & $* * *$ & 4.043 & 5.40 & $* * *$ \\
\hline No. of observations & 2,788 & & & 2,788 & & \\
\hline Wald $\mathrm{chi}^{2}$ & 229.7 & $* * *$ & & 263.5 & $* * *$ & \\
\hline Log Likelihood & $-5,352.2$ & & & $-5,346.2$ & & \\
\hline
\end{tabular}

*, **, ***: statistically significant at the 10\%, 5\%, 1\% level. M.E.: marginal effect

a) Results from separate model estimations excluding IS_ER1 to IS_ER8.

All models include industry dummies which are jointly significant.

Source: ZEW: Mannheim Innovation Panel, survey 2003.

With regard to product innovations triggered by environmental regulation, we find a positive effect on firm profitability for regulations in the field of resource efficiency, though this effect is statistically significant at the 10 percent level only. This positive performance impact is strongly related to firms in the machinery and equipment sector (including the manufacture of control instruments) and in engineering services. These firms develop new production technology in response to regulatory requirements to reduce hazardous material or other resource input. As their clients are required to implement these new technologies, technology producers are obviously able to add a premium over their costs on sales prices. A further positive impact of innovation inducing environmental regulation on firm profitability relates to the field of recycling and waste management. We find a significant effect on the price-cost margin only when combining innovation sources for product and process innovations, however.

Other sources of innovation have little impact on firm profitability. A weakly significant positive impact on profit margins can be found for firms with product innovations that utilise new findings from public science. There is also a weak negative impact from product innovations 
that were triggered by unspecified regulations. As we do not know which regulations exactly were behind these innovations, it remains unclear what type of regulation actually hurts firm profitability, particularly as firms reporting both low profit margins and innovations driven by unspecified regulations do not show any industry focus.

Innovation activities contribute to higher price-cost margins. Firms with market novelties generated profit margins that are about 0.75 percentage points higher than for firms without new-to-the-market products. Cost reducing process innovations have only very small positive profit impacts which are not statistically significant at a reliable level. Firms with productrange novelties do not achieve any higher profits. In addition, the stock of patents has a positive effect on firm profitability while past R\&D has not. Since past R\&D refers to R\&D expenditure over sales in 2001 while price-cost margin is for 2002, the insignificant impact may point, on the one hand, to longer time lags between $R \& D$ investment and likely profitability impacts. On the other hand, R\&D may positively influence profits only if successful innovations with a certain degree of novelty have been introduced or significant unit cost reductions have been implemented. Since we directly measure these results of R\&D activity in our model, their are hardly any remaining effects of R\&D on profit margins.

Among the control variables, we find the expected positive impacts of concentration, export activity, foreign ownership and age while the capital-labour has no statistically significant effects on profit margins. We also cannot find any statistical effect for the interaction term of $\mathrm{R} \& \mathrm{D}$ and concentration.

\section{Conclusion}

This paper investigated the role of environmental regulation for innovation success and firm profitability based on unique firm-level data from Germany which allow to identify the actual regulations (laws, directives, standards etc.) that drove certain innovations. The analysis aims to contribute to the discussion of the Porter hypothesis postulating a positive effect of environmental regulation on the competitiveness of firms. Thus we focus on regulation-driven environmental innovations. For other environmental innovations which are not driven by regulation but by market demand or cost savings, we refer to other papers such as Rennings and Rammer (2009).

We were able to classify environmental innovations by the field of environmental policy that provided the main stimulus and to link this information to success measures for innovation 
(degree of novelty, sales with new products, cost reduction through new processes) as well to firm performance (price-cost margin). Since our data set is representative for the German firm population in a large number of sectors, our results provide insight into the likely role of environmental regulation for innovation on the firm level.

Theoretical considerations do not provide clear conclusions on the likely impacts of environmental regulation on innovation success and firm profitability. On the one hand, environmental regulation may urge firms to adopt standard technology and follow pre-defined paths of technological solutions which may reduce the degree of novelty of their innovative activities. Innovations triggered by environmental regulation may also be associated with higher costs in order to fulfil certain environmental standards which may reduce firm profitability. On the other hand, environmental regulation can reduce technology and market uncertainty of innovators and generate high demand for innovations as it urges users to adopt certain types of environmental friendly technology. Producers of such technology could be able to yield higher innovation success in terms of high sales soon after market launch. As users may also have few outside options, producers of environmental friendly technology may benefit from a strong bargaining position which can result in higher price-cost margins.

Consistent with the ambiguous results from theory, we cannot find a uniform impact of environmental regulations on innovation success and profitability. Aggregating across product and process innovation, environmental regulations do neither positively nor negatively affect innovation success in terms of the degree of novelty or the direct economic results of innovations (sales, cost reduction). There is also no general effect of environmental regulation on a firm's price-cost margin. The results become more disperse, however, when differentiating by field of environmental policy and by the type of innovation triggered by environmental regulation. We find that firms with innovations based on regulations in the field of sustainable mobility (e.g. low emission standards for cars) are able to generate significantly higher sales share with market novelties. Most firms with product innovations in this field (e.g. manufacturers of cars, automotive components, railways, ships, aircrafts as well as mobility services and engineering services) act on international markets. This suggests that there is a highly responsive international demand for new mobility products that fulfil German environmental regulation standards. Beise and Rennings (2005) argued that such a situation may constitute a lead market characteristic of environmental policy. Domestic regulation fosters innovations which are also accepted in other countries, i.e. which fit to environmental regulations abroad. 
In two other areas of environmental policy -water management and power generation- we find the opposite result, i.e. a negative effects of environmental regulation on innovation success. In both fields, firms with innovations triggered by respective regulative requirements are less likely to introduce market novelties but rather focus their innovative efforts on adopting already existing technology. This result may either indicate that German regulation in these fields is adaptive to international standards and applies regulation schemes introduced earlier in other countries. On the other hand, a low propensity to introduce new-to-the-market innovations could also reflect a later stage of innovative effects of regulation. At least in the area of water management, many regulations date back to the 1980s and early 1990s. Firms that still innovate based on these standards tend to be "late followers" that introduced new products to their portfolio that have been introduced by other firms many years before.

Interestingly, we cannot find any significant effect of environmental regulation on the size of cost reductions stemming from process innovation. This means that process innovations triggered by new environmental standards are cost efficient and do not fall behind conventional process innovation aimed at increasing production efficiency. We also do not find significant effects of environmental regulation on the probability to introduce product-range novelties (i.e. innovations that expand a firm's product portfolio) nor on the sales share generated by such innovations. This result suggests that regulation does not provide incentives to enter into new markets or open up new business fields.

The effect of innovations triggered by environmental regulation on a firm's profitability is ambiguous. Process innovations stimulated by this type of regulation exert a negative impact on the price-cost margin, indicating higher costs for firms to comply with regulation requirements for less environmentally harmful production techniques. When looking at individual fields of environmental policy, process innovations driven by sustainable mobility regulations show the largest negative impact of profit margins. Such process innovation typically take place in transportation, logistics and other distribution services. Fierce international competition obviously restricts German firms from passing on higher costs associated with environmental regulations to customers. But there are also positive profitability effects of environmental regulation. Firms with innovations triggered by regulations on recycling and waste management are able to achieve slightly higher price-cost margins which may be attributed to more cost efficient production (e.g. a reduction in material costs). In addition, we find a positive profitability impact of product innovations motivated by regulations on increasing. resource efficiency (which particularly relates to avoiding hazardous substances). As users of 
materials are urged by law to avoid certain hazardous materials at some point in time (e.g. the use of lead), producers of materials avoiding these substances tend to have some bargaining power over their customers which can be transferred into higher product prices.

Summing up, the conclusion is that environmental innovations on average do not perform worse compared to other innovations. This means that Porter is right when saying that environmental innovations do not harm the competitiveness of firms in general . However, if we look at specific environmental policy fields, we find winners and losers of environmental policy. For example, the innovators in the vehicle sector - e.g. suppliers of the automobile industry - have achieved above average sales shares. However, the adopters of these innovations in the transport industry had to pay the costs, and may have in fact experienced a loss of competitiveness. In other environmental technology fields such as waste and recycling it may have been easier to pass through the additional cost to the customer, and in the field of resource efficiency some cost savings may have offset the costs.

Our analysis has of course several limitations and shortcomings. First, the analysis rests on a single observation year from a single country, which naturally restricts a generalisation of our results. Longitudinal data would certainly be helpful in order to learn more about the time dimension between environmental regulation and innovation. In future research, we plan to make a step in this direction be utilising information from the 2009 innovation survey which again contained a question on regulations that triggered environmental innovations. More importantly, data from other countries would be extremely helpful to determine whether the impacts found in this study are specific to German environmental policy or whether they can be found in other countries too. Since the European Community Innovation Survey conducted in 2009 contained a separate question on environmental innovations and their drivers, we are confident that new opportunities for international comparisons on the effects of environmental regulations on firms' innovation activities will be served with promising new empirical data.

\section{Literature}

Arimura, T., A. Hibiki, N. Johnstone (2007), An Empirical Study of Environmental R\&D: What encourages Facilities to be Environmentally Innovative?, in N. Johnstone (ed.), Environmental Policy and Corporate Behaviour, Aldershot: Edward Elgar, 142-173.

Arundel, A., R. Kemp (2009), Measuring eco-innovation. United Nations University - Maastricht Economic and social Research and training centre on Innovation and Technology UNU-MERIT, Working paper series, 2009-017 
Ashford, N., C. Ayers, R. Stone (1985), Using Regulation as to Change the Market for Innovation, Harvard Environmental Law Review 9, 419-466.

Beise, M., T. Cleff (2004), Assessing the Lead Market Potential of Countries for Innovation Projects, Journal of International Management 10, 453-477.

Beise, M., C. Rammer (2006), Local User-Producer Interaction in Innovation and Export Performance of Firms, Small Business Economics 27, 207-222.

Beise, M., K. Rennings (2005), Lead Markets and Regulation: A Framework for Analyzing the International Diffusion of Environmental Innovation, Ecological Economics 52, 5-17.

Blazejczak, J., D. Edler, J. Hemmelskamp, M. Jänicke (1999), Environmental Policy and Innovation an International Comparison of Policy Frameworks and Innovation Effects, in P. Klemmer (ed.), Innovation and the Environment, Berlin: Analytica, 9-30.

Brunnermeier, S.B., M.A. Cohen (2003), Determinants of environmental innovation in US manufacturing industries, Journal of Environmental Economics and Management 45, 278-293.

Cleff, T., K. Rennings (1999), Determinants of Environmental Product and Process Innovation - Evidence from the Mannheim Innovation Panel and a Follow-Up Telephone Survey, European Environment 9, 191-201.

Czarnitzki, D., K. Kraft (2010), On the Profitability of Innovative Assets, Applied Economics 42, 1941-1953

Del Rio Gonzalez, P. (2005), Analysing the Factors Influencing Clean Technology Adoption: A Study of the Spanish Pulp and Paper Industry, Business Strategy and the Environment 14, 20-37.

Frondel, M., J. Horbach, K. Rennings (2007), End-of-Pipe or Cleaner Production? An Empirical Comparison of Environmental Innovation Decisions Across OECD Countries, Business Strategy and the Environment 16, 571-584.

Geroski, P., S. Machin, J. van Reenen (1993), The Profitability of Innovating Firms, RAND Journal of Economics 24, 198-211.

Grabowski H.G., D.C. Mueller (1978), Industrial Research and Development, Intangible Capital Stocks and Firm Profit Rates, Bell Journal of Economics 9, 328-343.

Green, K., A. McMeekin, A. Irwin (1994), Technological trajectories and R\&D for Environmental Innovation in UK Firms, Futures 26, 1047-1059.

Heckman, J. (1979), Sample selection bias as a specification error, Econometrica 47, 153-161.

Horbach, J. (2008), Determinants of Environmental Innovation - New Evidence from German Panel Data Sources, Research Policy 37, 163-173.

Jaffe, A.B., R.G. Newell, R.N. Stavins (2002), Environmental Policy and Technological Change, Environmental and Resource Economics 22, 41-69.

Janz, N., G. Ebling, S. Gottschalk, H. Niggemann (2001), The Mannheim Innovation Panels (MIP and MIP-S) of the Centre for European Economic Research (ZEW), Journal of Applied Social Science Studies 121, 123-129.

Kammerer, D. (2009), The effects of customer benefit and regulation on environmental product innovation. Empirical evidence from appliance manufacturers in Germany, Ecological Economics 68, 2285-2295. 
Kemp, R., P. Pearson (2007), Final report MEI project about measuring eco-innovation, Maastricht, www.merit.unu.edulMEI

OECD, Eurostat (2005), Oslo Manual - Guidelines for Collecting and Interpreting Innovation Data. Third Edition, Paris: Organisation for Economic Co-Operation and Development.

Peters, B. (2008), Innovation and Firm Performance. An Empirical Investigation for German Firms, ZEW Economic Studies 38, Heidelberg: Physica.

Popp, D. (2006), International Innovation and Diffusion of Air Pollution Control Technologies: The Effects of $\mathrm{NO}_{\mathrm{x}}$ and $\mathrm{SO}_{2}$ Regulation in the US, Japan, and Germany, Journal of Environmental Economics and Management 51, 46-71.

Porter, M.E., C. van der Linde (1995a), Towards a New Conception of the Environment-Competitiveness Relationship, Journal of Economic Perspectives 9, 97-118.

Porter, M.E., C. van der Linde (1995b), Green and Competitive. Ending the Stalemate, Harvard Business Review 09-10/1995, 120-134.

Rammer, C., B. Peters, T. Schmidt, B. Aschhoff, T. Doherr, H. Niggemann (2005), Innovationen in Deutschland. Ergebnisse der Innovationserhebung 2003 in der deutschen Wirtschaft, ZEW Wirtschaftsanalysen, Bd. 78, Baden-Baden: Nomos.

Rammer, C., D. Czarnitzki, A. Spielkamp (2009), Innovation success of non-R\&D-performers: substituting technology by management in SMEs, Small Business Economics 33, 35-58.

Rehfeld, K., K. Rennings, A. Ziegler (2007), Determinants of Environmental Product Innovations and the Role of Integrated Product Policy - An Empirical Analysis; Ecological Economics 61, 91-100.

Rennings, K. (2000), Redefining Innovation - Eco-Innovation Research and the Contribution from Ecological Economics, Ecological Economics 32, 319-332.

Rennings, K., T. Zwick (2002), The Employment Impact of Cleaner Production on the Firm Level Empirical evidence from a Survey in Five European Countries, International Journal of Innovation Management 6, 319-342.

Rennings, K., C. Rammer (2009), Increasing energy and resource efficiency through innovation - an explorative analysis using innovation survey data, Czech Journal of Economics and Finance (CJEF) 59, 442-459.

Van den Bergh, J.C.J.M. (2008), Environmental regulation of households: An empirical review of economic and psychological factors, Ecological Economics 66, 559-574. 


\section{Appendix}

Table A1: Descriptive statistics for variables used in models on innovation success

\begin{tabular}{|c|c|c|c|c|c|}
\hline Variable & Definition & Mean & Std. Dev. & Min & Max \\
\hline \multicolumn{6}{|c|}{ a. Models [1] on MN, PN (for $P D=1$ ) } \\
\hline $\mathrm{MN}$ & Market novelities & 0.57 & 0.50 & 0 & 1 \\
\hline $\mathrm{PN}$ & Product-range novelties & 0.56 & 0.50 & 0 & 1 \\
\hline IS_ER & Innovation source environmental regulations & 0.10 & 0.30 & 0 & 1 \\
\hline IS_ER1 & Env. reg. in air quality management & 0.01 & 0.08 & 0 & 1 \\
\hline IS_ER2 & Env. reg. in power generation & 0.01 & 0.11 & 0 & 1 \\
\hline IS_ER3 & Env. reg. in resource efficiency, dangerous materials & 0.01 & 0.10 & 0 & 1 \\
\hline IS_ER4 & Env. reg. in recycling, waste management & 0.01 & 0.10 & 0 & 1 \\
\hline IS_ER5 & Env. reg. in water management & 0.01 & 0.08 & 0 & 1 \\
\hline IS_ER6 & Env. reg. in sustainable mobility & 0.01 & 0.08 & 0 & 1 \\
\hline IS_ER7 & Env. reg. in energy efficiency & 0.01 & 0.07 & 0 & 1 \\
\hline IS_ER8 & Env. reg. regulations unspecified & 0.04 & 0.20 & 0 & 1 \\
\hline IS_OR & Innovation source other regulations & 0.10 & 0.30 & 0 & 1 \\
\hline IS_UR & Innovation source regulations unspecified & 0.04 & 0.19 & 0 & 1 \\
\hline IS_CS & Innovation source customers & 0.66 & 0.47 & 0 & 1 \\
\hline IS_SP & Innovation source suppliers & 0.20 & 0.40 & 0 & 1 \\
\hline IS_CP & Innovation source competitors & 0.16 & 0.37 & 0 & 1 \\
\hline IS_SC & Innovation source public science & 0.28 & 0.45 & 0 & 1 \\
\hline NOIS & Innovators without innovation source & 0.20 & 0.40 & 0 & 1 \\
\hline PC & Process innovator & 0.57 & 0.50 & 0 & 1 \\
\hline SIZE & Ln (no. employees at FTE) & 4.36 & 1.91 & 0.0 & 12.9 \\
\hline RDC & Continuous in-house $R \& D$ activity & 0.62 & 0.49 & 0 & 1 \\
\hline $\mathrm{RDO}$ & Occasional in-house R\&D activity & 0.15 & 0.36 & 0 & 1 \\
\hline HUC & Share of graduated employees & 0.30 & 0.28 & 0 & 1 \\
\hline COOP & Cooperation in innovation activities & 0.54 & 0.50 & 0 & 1 \\
\hline EAST & Location in East Germany & 0.32 & 0.47 & 0 & 1 \\
\hline \multicolumn{6}{|c|}{ b. Models [2] on CO (for PC=1) } \\
\hline $\mathrm{CO}$ & Cost reduction through process innovation & 0.59 & 0.49 & 0 & 1 \\
\hline IS_ER & Innovation source environmental regulations & 0.05 & 0.21 & 0 & 1 \\
\hline IS_ER1 & Env. reg. in air quality management & 0.00 & 0.07 & 0 & 1 \\
\hline IS_ER2 & Env. reg. in power generation & 0.00 & 0.05 & 0 & 1 \\
\hline IS_ER3 & Env. reg. in resource efficiency, dangerous materials & 0.01 & 0.07 & 0 & 1 \\
\hline IS_ER4 & Env. reg. in recycling, waste management & 0.01 & 0.07 & 0 & 1 \\
\hline IS_ER5 & Env. reg. in water management & 0.00 & 0.05 & 0 & 1 \\
\hline IS_ER6 & Env. reg. in sustainable mobility & 0.00 & 0.05 & 0 & 1 \\
\hline IS_ER7 & Env. reg. in energy efficiency & 0.00 & 0.06 & 0 & 1 \\
\hline IS_ER8 & Env. reg. regulations unspecified & 0.02 & 0.14 & 0 & 1 \\
\hline IS_OR & Innovation source other regulations & 0.04 & 0.19 & 0 & 1 \\
\hline IS_UR & Innovation source regulations unspecified & 0.01 & 0.11 & 0 & 1 \\
\hline IS_CS & Innovation source customers & 0.21 & 0.41 & 0 & 1 \\
\hline IS_SP & Innovation source suppliers & 0.11 & 0.31 & 0 & 1 \\
\hline IS_CP & Innovation source competitors & 0.06 & 0.24 & 0 & 1 \\
\hline IS_SC & Innovation source public science & 0.11 & 0.32 & 0 & 1 \\
\hline NOIS & Innovators without innovation source & 0.63 & 0.48 & 0 & 1 \\
\hline $\mathrm{PD}$ & Product innovator & 0.86 & 0.35 & 0 & 1 \\
\hline SIZE & Ln (no. employees at FTE) & 4.60 & 1.95 & 0 & 12.94 \\
\hline $\mathrm{RDC}$ & Continuous in-house R\&D activity & 0.57 & 0.50 & 0 & 1 \\
\hline $\mathrm{RDO}$ & Occasional in-house R\&D activity & 0.15 & 0.36 & 0 & 1 \\
\hline HUC & Share of graduated employees & 0.27 & 0.27 & 0 & 1 \\
\hline COOP & Cooperation in innovation activities & 0.58 & 0.49 & 0 & 1 \\
\hline EAST & Location in East Germany & 0.32 & 0.47 & 0 & 1 \\
\hline \multicolumn{6}{|c|}{ c. Model [3] on SM (for MN=1) } \\
\hline SM & Share of sales generated by market novelties & 19.29 & 23.08 & 0 & 1 \\
\hline
\end{tabular}




\begin{tabular}{|c|c|c|c|c|c|}
\hline IS_ER & Innovation source environmental regulations & 0.09 & 0.29 & 0 & 1 \\
\hline IS_ER1 & Env. reg. in air quality management & 0.01 & 0.08 & 0 & 1 \\
\hline IS_ER2 & Env. reg. in power generation & 0.01 & 0.09 & 0 & 1 \\
\hline IS_ER3 & Env. reg. in resource efficiency, dangerous materials & 0.01 & 0.12 & 0 & 1 \\
\hline IS_ER4 & Env. reg. in recycling, waste management & 0.01 & 0.10 & 0 & 1 \\
\hline IS_ER5 & Env. reg. in water management & 0.01 & 0.07 & 0 & 1 \\
\hline IS_ER6 & Env. reg. in sustainable mobility & 0.01 & 0.10 & 0 & 1 \\
\hline IS_ER7 & Env. reg. in energy efficiency & 0.00 & 0.06 & 0 & 1 \\
\hline IS_ER8 & Env. reg. regulations unspecified & 0.04 & 0.19 & 0 & 1 \\
\hline IS_OR & Innovation source other regulations & 0.10 & 0.30 & 0 & 1 \\
\hline IS_UR & Innovation source regulations unspecified & 0.03 & 0.17 & 0 & 1 \\
\hline IS_CS & Innovation source customers & 0.70 & 0.46 & 0 & 1 \\
\hline IS_SP & Innovation source suppliers & 0.22 & 0.42 & 0 & 1 \\
\hline IS_CP & Innovation source competitors & 0.21 & 0.41 & 0 & 1 \\
\hline IS_SC & Innovation source public science & 0.27 & 0.44 & 0 & 1 \\
\hline NOIS & Innovators without innovation source & 0.17 & 0.37 & 0 & 1 \\
\hline PC & Process Innovator & 0.59 & 0.49 & 0 & 1 \\
\hline SIZE & Ln (no. employees at FTE) & 4.42 & 1.98 & 0 & 11.89 \\
\hline IES & Innovation expenditure, share in sales & 0.20 & 0.60 & 0 & 9.6 \\
\hline EAST & Location in East Germany & 0.30 & 0.46 & 0 & 1 \\
\hline \multicolumn{6}{|c|}{ d. Model [3] on SP (for $\mathbf{P N}=1)$} \\
\hline SP & Share of sales generated by product-range novelties & 19.13 & 23.53 & 0 & 1 \\
\hline IS_ER & Innovation source environmental regulations & 0.09 & 0.29 & 0 & 1 \\
\hline IS_ER1 & Env. reg. in air quality management & 0.01 & 0.09 & 0 & 1 \\
\hline IS_ER2 & Env. reg. in power generation & 0.01 & 0.10 & 0 & 1 \\
\hline IS_ER3 & Env. reg. in resource efficiency, dangerous materials & 0.01 & 0.10 & 0 & 1 \\
\hline IS_ER4 & Env. reg. in recycling, waste management & 0.01 & 0.10 & 0 & 1 \\
\hline IS_ER5 & Env. reg. in water management & 0.01 & 0.09 & 0 & 1 \\
\hline IS_ER6 & Env. reg. in sustainable mobility & 0.01 & 0.07 & 0 & 1 \\
\hline IS_ER7 & Env. reg. in energy efficiency & 0.00 & 0.05 & 0 & 1 \\
\hline IS_ER8 & Env. reg. regulations unspecified & 0.04 & 0.19 & 0 & 1 \\
\hline IS_OR & Innovation source other regulations & 0.11 & 0.32 & 0 & 1 \\
\hline IS_UR & Innovation source regulations unspecified & 0.03 & 0.18 & 0 & 1 \\
\hline IS_CS & Innovation source customers & 0.68 & 0.47 & 0 & 1 \\
\hline IS_SP & Innovation source suppliers & 0.21 & 0.41 & 0 & 1 \\
\hline IS_CP & Innovation source competitors & 0.20 & 0.40 & 0 & 1 \\
\hline IS_SC & Innovation source public science & 0.29 & 0.45 & 0 & 1 \\
\hline NOIS & Innovators without innovation source & 0.18 & 0.38 & 0 & 1 \\
\hline PC & Process Innovator & 0.60 & 0.49 & 0 & 1 \\
\hline SIZE & Ln (no. employees at FTE) & 4.31 & 1.99 & 0.67 & 11.89 \\
\hline IES & Innovation expenditure, share in sales & 0.22 & 0.96 & 0 & 20.0 \\
\hline EAST & Location in East Germany & 0.33 & 0.47 & 0 & 1 \\
\hline \multicolumn{6}{|c|}{ e. Model [3] on RC (for $\mathrm{CO}=1)$} \\
\hline SP & Share of sales generated by product-range novelties & 9.83 & 9.30 & 0.001 & 0.800 \\
\hline IS_ER & Innovation source environmental regulations & 0.05 & 0.22 & 0 & 1 \\
\hline IS_ER1 & Env. reg. in air quality management & 0.01 & 0.09 & 0 & 1 \\
\hline IS_ER2 & Env. reg. in power generation & 0.00 & 0.06 & 0 & 1 \\
\hline IS_ER3 & Env. reg. in resource efficiency, dangerous materials & 0.01 & 0.07 & 0 & 1 \\
\hline IS_ER4 & Env. reg. in recycling, waste management & 0.00 & 0.04 & 0 & 1 \\
\hline IS_ER5 & Env. reg. in water management & 0.00 & 0.06 & 0 & 1 \\
\hline IS_ER6 & Env. reg. in sustainable mobility & 0.00 & 0.06 & 0 & 1 \\
\hline IS_ER7 & Env. reg. in energy efficiency & 0.00 & 0.06 & 0 & 1 \\
\hline IS_ER8 & Env. reg. regulations unspecified & 0.02 & 0.14 & 0 & 1 \\
\hline IS_OR & Innovation source other regulations & 0.04 & 0.20 & 0 & 1 \\
\hline IS_UR & Innovation source regulations unspecified & 0.02 & 0.13 & 0 & 1 \\
\hline IS_CS & Innovation source customers & 0.20 & 0.40 & 0 & 1 \\
\hline IS_SP & Innovation source suppliers & 0.13 & 0.34 & 0 & 1 \\
\hline IS_CP & Innovation source competitors & 0.07 & 0.25 & 0 & 1 \\
\hline IS_SC & Innovation source public science & 0.10 & 0.30 & 0 & 1 \\
\hline NOIS & Innovators without innovation source & 0.62 & 0.49 & 0 & 1 \\
\hline PC & Process Innovator & 0.85 & 0.36 & 0 & 1 \\
\hline
\end{tabular}




\begin{tabular}{lllrrr} 
SIZE & Ln (no. employees at FTE) & 4.90 & 1.96 & 0.63 & 12.31 \\
IES & Innovation expenditure, share in sales & 0.11 & 0.39 & 0 & 6.8 \\
EAST & Location in East Germany & 0.28 & 0.45 & 0 & 1 \\
\hline
\end{tabular}

Source: ZEW: Mannheim Innovation Panel, survey 2003.

Table A3: Impact of environmental regulations as a source for innovation on innovation success: estimation results of Tobit models

\begin{tabular}{|c|c|c|c|c|c|c|c|c|c|}
\hline \multirow{2}{*}{$\begin{array}{l}\text { Introduction of novelties/cost } \\
\text { reduction (yes/no) }\end{array}$} & \multicolumn{3}{|c|}{$\mathrm{MN}$} & \multicolumn{3}{|c|}{ PN } & \multicolumn{3}{|c|}{$\mathrm{CO}$} \\
\hline & Coeff. & \multicolumn{2}{|c|}{ t-value } & Coeff. & \multicolumn{2}{|c|}{ t-value } & Coeff & \multicolumn{2}{|c|}{ t-value } \\
\hline IS_ER ${ }^{\text {a) }}$ & -0.031 & -0.99 & & -0.048 & -1.52 & & 0.022 & 0.40 & \\
\hline IS_ER1 (air quality ) & 0.017 & 0.14 & & 0.090 & 0.82 & & 0.029 & 0.41 & \\
\hline IS_ER2 (power generation) & -0.147 & -1.57 & & -0.077 & -0.86 & & 0.035 & 0.31 & \\
\hline IS_ER3 (resource efficiency) & 0.055 & 0.68 & & 0.007 & 0.08 & & -0.017 & -0.26 & \\
\hline IS_ER4 (recycling, waste) & 0.056 & 0.60 & & 0.002 & 0.02 & & -0.089 & -1.09 & \\
\hline IS_ER5 (water management) & -0.223 & -1.99 & ** & -0.055 & -0.54 & & 0.080 & 0.82 & \\
\hline IS_ER6 (sustainable mobility) & 0.309 & 2.90 & $* * *$ & 0.127 & 1.06 & & 0.069 & 0.71 & \\
\hline IS_ER7 (energy efficiency) & -0.027 & -0.22 & & -0.124 & -0.86 & & 0.050 & 0.64 & \\
\hline IS_ER8 (unspecified) & -0.052 & -1.15 & & -0.104 & -2.22 & ** & -0.080 & -2.15 & $* *$ \\
\hline IS_OR & -0.032 & -1.08 & & -0.005 & -0.18 & & 0.045 & 1.73 & $*$ \\
\hline IS_UR & 0.003 & 0.06 & & 0.010 & 0.20 & & 0.088 & 2.05 & $* *$ \\
\hline IS_CS & 0.057 & 2.14 & $* *$ & -0.020 & -0.75 & & 0.027 & 1.62 & \\
\hline IS_SP & 0.012 & 0.51 & & 0.007 & 0.29 & & 0.054 & 3.01 & $* * *$ \\
\hline IS_CP & -0.050 & -2.38 & $* *$ & -0.012 & -0.57 & & -0.006 & -0.34 & \\
\hline IS_SC & 0.066 & 2.66 & $* * *$ & 0.073 & 2.84 & $* * *$ & 0.053 & 2.45 & $* *$ \\
\hline NOIS & -0.005 & -0.13 & & -0.040 & -1.18 & & 0.037 & 2.01 & $* *$ \\
\hline PC & 0.029 & 1.57 & & 0.039 & 2.09 & $* *$ & & & \\
\hline PD & & & & & & & -0.017 & -1.22 & \\
\hline SIZE & -0.016 & -2.76 & $* * *$ & -0.066 & -3.48 & $* * *$ & -0.022 & -2.01 & $* *$ \\
\hline SIZE2 & & & & & & & 0.002 & 2.21 & $* *$ \\
\hline IES & 0.076 & 5.84 & $* * *$ & 0.057 & 5.80 & $* * *$ & -0.004 & -0.67 & \\
\hline RDC & 0.071 & 2.93 & $* * *$ & 0.009 & 0.36 & & 0.020 & 1.58 & \\
\hline RDO & -0.002 & -0.06 & & -0.037 & -1.24 & & 0.019 & 1.23 & \\
\hline HUC & 0.118 & 2.74 & $*$ & 0.050 & 1.13 & & -0.038 & -1.52 & \\
\hline COOP & 0.025 & 1.30 & & 0.026 & 1.32 & & -0.011 & -1.13 & \\
\hline EAST & -0.055 & -2.84 & $* * *$ & 0.008 & 0.42 & & -0.026 & -2.48 & $* *$ \\
\hline Constant & 0.125 & -1.87 & $*$ & 0.040 & 2.25 & $* *$ & -0.044 & 1.96 & ** \\
\hline No. of observations & 1,324 & & & 1,318 & & & 922 & & \\
\hline No. of uncensored observations & 704 & & & 702 & & & 511 & & \\
\hline LR chi $^{2}$ & 200.3 & $* * *$ & & 160.1 & $* * *$ & & 73.6 & $* *$ & \\
\hline
\end{tabular}

$*, * *, * * *$ : statistically significant at the $10 \%, 5 \%, 1 \%$ level.

a) Results from separate model estimations excluding IS_ER1 to IS_ER8.

All models include industry dummies which are jointly significant. Their coefficients are omitted due to lack of space.

Source: ZEW: Mannheim Innovation Panel, survey 2003.

Table A4: Descriptive statistics for variables used in models on firm performance

\begin{tabular}{|c|c|c|c|c|c|}
\hline Variable & Definition & Mean & Std. Dev. & Min & Max \\
\hline PCM & Price-cost margin (seven categories) & 2.27 & 1.80 & 0 & 6 \\
\hline IS_ER (PD or PC=1) & Innovation source environment. regulations (all inn.) & 0.043 & 0.203 & 0 & 1 \\
\hline IS_ER1 (PD or PC=1) & Env. reg. in air quality management (all inn.) & 0.004 & 0.060 & 0 & 1 \\
\hline IS_ER2 (PD or PC=1) & Env. reg. in power generation (all inn.) & 0.006 & 0.076 & 0 & 1 \\
\hline IS_ER3 (PD or PC=1) & Env. reg. in resource effic., dangerous mat. (all inn.) & 0.005 & 0.071 & 0 & 1 \\
\hline IS_ER4 (PD or PC=1) & Env. reg. in recycling, waste management (all inn.) & 0.005 & 0.071 & 0 & 1 \\
\hline IS_ER5 (PD or PC=1) & Env. reg. in water management (all inn.) & 0.003 & 0.057 & 0 & 1 \\
\hline IS_ER6 (PD or PC=1) & Env. reg. in sustainable mobility (all inn.) & 0.004 & 0.065 & 0 & 1 \\
\hline IS_ER7 (PD or PC=1) & Env. reg. in energy efficiency (all inn.) & 0.004 & 0.060 & 0 & 1 \\
\hline
\end{tabular}




\begin{tabular}{|c|c|c|c|c|c|}
\hline IS_ER8 (PD or PC=1) & Environmental regulations unspecified (all inn.) & 0.017 & 0.129 & 0 & \\
\hline IS_OR (PD or PC=1) & Innovation source other regulations (all inn.) & 0.051 & 0.221 & 0 & \\
\hline IS_UR (PD or PC=1) & Innovation source regulations unspecified (all inn.) & 0.016 & 0.125 & & \\
\hline IS_CS (PD or PC=1) & Innovation source customers (all inn.) & 0.282 & 0.450 & 0 & \\
\hline IS_SP (PD or PC=1) & Innovation source suppliers (all inn.) & 0.099 & 0.299 & 0 & \\
\hline IS_CP (PD or PC=1) & Innovation source competitors (all inn.) & 0.071 & 0.258 & 0 & \\
\hline IS_SC (PD or PC=1) & Innovation source public science (all inn.) & 0.128 & 0.334 & 0 & \\
\hline NOIS (PD or PC=1) & Innovators without external source (all inn.) & 0.033 & 0.179 & 0 & \\
\hline IS_ER $(\mathrm{PD}=1)$ & Product innovation source environmental regulations & 0.040 & 0.196 & 0 & \\
\hline IS_ER1 (PD=1) & Env. reg. in air quality management (pd. inn.) & 0.002 & 0.046 & 0 & \\
\hline IS_ER2 (PD=1) & Env. reg. in power generation (pd. inn.) & 0.005 & 0.073 & 0 & \\
\hline IS_ER3 $(\mathrm{PD}=1)$ & Env. reg. in resource effic., dangerous mat. (pd. inn.) & 0.004 & 0.063 & 0 & \\
\hline IS_ER4 (PD=1) & Env. reg. in recycling, waste management (pd. inn.) & 0.005 & 0.068 & 0 & \\
\hline IS_ER5 (PD=1) & Env. reg. in water management (pd. inn.) & 0.003 & 0.053 & 0 & \\
\hline IS_ER6 $(\mathrm{PD}=1)$ & Env. reg. in sustainable mobility (pd. inn.) & 0.004 & 0.063 & 0 & \\
\hline IS_ER7 (PD=1) & Env. reg. in energy efficiency (pd. inn.) & 0.002 & 0.046 & 0 & \\
\hline IS_ER8 (PD=1) & Environmental regulations unspecified (pd. inn.) & 0.015 & 0.122 & 0 & \\
\hline IS_OR $(\mathrm{PD}=1)$ & Product innovation source other regulations & 0.042 & 0.201 & 0 & \\
\hline IS_UR $(P D=1)$ & Product innovation source regulations unspecified & 0.015 & 0.123 & 0 & \\
\hline IS_CS (PD=1) & Product innovation source customers & 0.270 & 0.444 & 0 & \\
\hline IS_SP $(\mathrm{PD}=1)$ & Product innovation source suppliers & 0.082 & 0.275 & 0 & \\
\hline IS_CP (PD=1) & roduct innovation source competitors & 0.065 & 0.247 & 0 & \\
\hline IS_SC (PD=1) & Product innovation source public science & 0.114 & 0.318 & 0 & \\
\hline NOIS $(\mathrm{PD}=1)$ & Product innovators without innovation source & 0.085 & 0.279 & 0 & \\
\hline IS_ER $(P C=1)$ & Process innovation source environmental regulations & 0.014 & 0.116 & 0 & \\
\hline IS_ER1 $(\mathrm{PC}=1)$ & dality management (pc. inn.) & 0.001 & 0.038 & & \\
\hline IS_ER2 (PC=1) & Env. reg. in power generation (pc. inn.) & 0.001 & 0.033 & 0 & \\
\hline IS_ER3 $(\mathrm{PC}=1)$ & Env. reg. in resource effic., dangerous mat. (pc. inn.) & 0.002 & 0.042 & 0 & \\
\hline IS_ER4 $(\mathrm{PC}=1)$ & §, waste management (pc. inn.) & 0.002 & 0.042 & 0 & \\
\hline IS_ER5 $(\mathrm{PC}=1)$ & Env. reg. in water management (pc. inn.) & 0.001 & 0.027 & 0 & \\
\hline IS_ER6 $(\mathrm{PC}=1)$ & Env. reg. in sustainable mobility (рс. inn.) & 0.001 & 0.033 & 0 & \\
\hline IS_ER7 (PC=1) & sy efficiency (pc. inn.) & 0.001 & 0.038 & 0 & \\
\hline IS_ER8 $(\mathrm{PC}=1)$ & Environmental regulations unspecified (pc. inn.) & 0.005 & 0.068 & 0 & \\
\hline IS_OR $(\mathrm{PC}=1)$ & Process innovation source other regulations & 0.013 & 0.113 & 0 & \\
\hline IS_UR (PC=1) & source regulations unspecified & 0.003 & 0.053 & 0 & \\
\hline IS_CS (PC=1) & Process innovation source customers & 0.056 & 0.231 & 0 & \\
\hline IS_SP (PC=1) & Process innovation source suppliers & 0.032 & 0.177 & 0 & \\
\hline IS_CP (PC=1) & Process innovation source competitors & 0.016 & 0.125 & 0 & \\
\hline IS_SC $(\mathrm{PC}=1)$ & e public science & 0.033 & 0.179 & 0 & \\
\hline NOIS $(P C=1)$ & Process innovators without external source & 0.173 & 0.378 & 0 & \\
\hline MN & Introduction of market novelties & 0.232 & 0.422 & 0 & \\
\hline PN & e novelties & 0.234 & 0.423 & 0 & \\
\hline $\mathrm{CO}$ & Introduction of cost reducing process. innov. & 0.166 & 0.372 & 0 & \\
\hline SIZE_L & Ln (no. employees at FTE), previous year & 3.93 & 1.81 & 0 & 12.3 \\
\hline FOR & & 0.076 & 0.266 & 0 & \\
\hline EXP & Export activities in the & 0.390 & 0.488 & 0 & \\
\hline HCI & Herfindahl concentration index (Nace 3-digit) & 36.8 & 80 & 0 & 1000 \\
\hline RDI & R\&D expenditure, share in sales, previous year & 0.045 & 0.362 & 0 & 14.0 \\
\hline HCI_RDI & $\mathrm{HCI} * \mathrm{RDI}$ & 1.34 & 8.85 & & 358 \\
\hline PAT & Ln (stock of patent applications), previous year & 0.591 & 1.356 & 0 & 9.79 \\
\hline NOPAT & Stock of patent applications is zero, previous year & 0.744 & 0.437 & 0 & \\
\hline CLR & Fixed assets per employee (at FTE), previous year & 0.095 & 0.674 & & 24.8 \\
\hline AGE & Ln (no. of years since firm foundation) & 2.80 & 1.05 & -0.69 & 6.22 \\
\hline EAST & Location in East Germany & 0.343 & 0.475 & 0 & \\
\hline
\end{tabular}

Source: ZEW: Mannheim Innovation Panel, survey 2003. 